\title{
BIOGEOCHEMISTRY AND NUTRIENT LIMITATION OF MICROBIAL BIOFILMS IN DEVILS HOLE, NEVADA
}

\author{
Hilary L. Madinger ${ }^{1}$, Kevin P. Wilson ${ }^{2}$, Jeffery A. Goldstein ${ }^{2}$, and Melody J. Bernot ${ }^{1,3}$
}

\begin{abstract}
AвsтRACT.-Little is known about the role of microbial biofilms in nutrient cycling and ecosystem processes within desert springs. However, biofilms produce microscale physicochemical variation important to ecosystem function. We used microelectrodes to measure microscale physicochemical (temperature, $\mathrm{pH}, \mathrm{O}_{2}$, and $\mathrm{H}_{2} \mathrm{~S}$ ) heterogeneity in biofilms at Devils Hole, Nevada. Additionally, we measured water column and pore water nutrient concentrations in 2 autotrophic (Spirogyra, cyanobacteria) and 1 heterotrophic (Beggiatoa) biofilm types. Spirogyra and cyanobacteria followed similar physicochemical trends; however, Spirogyra had more pronounced diurnal and seasonal variation. Oxygen concentrations within the biofilms varied with sample month, light availability, and biofilm type. We also assessed the nutrient limitation of desert spring microbial biofilms using a nutrient-diffusing substrata experiment. Autotrophic and heterotrophic biofilms responded differently to nutrient treatments. The differences between cyanobacteria and Spirogyra have implications on the ecosystem function of desert springs, as well as other ecosystems with diverse biofilm communities, and suggest that a change in microbial biofilms could alter ecosystem biogeochemical dynamics.
\end{abstract}

RESUMEn.-Se sabe poco sobre el papel de las biopelículas microbianas en los ciclos de los nutrientes y en los procesos del ecosistema dentro de los manantiales del desierto. Sin embargo, las biopelículas producen variación fisicoquímica a micro-escala, de relevancia para la función del ecosistema. Medimos la heterogeneidad fisicoquímica de biopelículas a micro-escala (temperatura, $\mathrm{pH}, \mathrm{O}_{2}$ y $\mathrm{H}_{2} \mathrm{~S}$ ) en Devils Hole, Nevada, utilizando micro-electrodos. Además, medimos la concentración de nutrientes de la columna de agua y del agua intersticial en dos tipos de biopelículas autótrofas (Spirogyra, cianobacterias) y en una heterótrofa (Beggiatoa). Las Spirogyra y las cianobacterias siguieron tendencias físico-químicas similares; sin embargo, las Spirogyra tuvieron variación diurna y estacional más pronunciada. Las concentraciones de oxígeno dentro de las biopelículas variaron de acuerdo a la muestra del mes, la disponibilidad de luz y el tipo de biopelícula. También evaluamos la limitación de nutrientes de las biopelículas microbianas de los manantiales del desierto realizando un experimento de difusión de sustratos de nutrientes. Las biopelículas autótrofas y las heterótrofas respondieron de manera diferente a los tratamientos de nutrientes. Las diferencias entre las cianobacterias y las Spirogyra tienen implicaciones en la función de los ecosistemas de los manantiales del desierto, así como sobre otros ecosistemas con diversas comunidades de biopelículas y sugieren que un cambio en las biopelículas microbianas podría alterar la dinámica de los ecosistemas biogeoquímicos.

Microbial biofilms are important heterogeneous communities of algae, bacteria, and invertebrates living on substrata in aquatic ecosystems. Microbial biofilms facilitate nutrient cycling (Murdock and Wetzel 2009), provide habitat for other organisms (Riggs and Deacon 2002), and can ameliorate nutrient enrichment (Grimm et al. 2005). Multiple species are distributed throughout heterogeneous biofilms, influencing the ecosystem physicochemical characteristics. Species distribution and abundance are dictated primarily by light (Barranguet et al. 2005) and nutrient availability (Fairchild et al. 1985, Biggs and Lowe 1994). Because of differences in process rates among species, unique chemical gradients can develop within biofilms. Additionally, organisms that live in or feed on the biofilms may be dependent on specific physicochemical gradients present. Changes in the distribution or seasonal abundance of biofilm species can alter the physicochemical characteristics of the biofilms, which in turn alter ecosystem process rates.

Microbial metabolism in aquatic ecosystems is limited by nutrient availability for both autotrophs (Fairchild et al. 1985) and heterotrophs (Tank and Dodds 2003), though the specific nutrient limitation of autotrophs and heterotrophs may differ (Pringle et al. 1986, Tank and Webster 1998, Johnson et al. 2009) within a given ecosystem. Additionally, nutrient limitation may influence species composition within aquatic communities (Francoeur

\footnotetext{
${ }^{1}$ Department of Biology, Ball State University, Muncie, IN 47306.

${ }^{2}$ Death Valley National Park, Pahrump, NV 89048.

${ }^{3}$ Corresponding author. E-mail: mjbernot@bsu.edu
} 
TABLE 1. Physical and chemical characteristics of 2 desert springs, Devils Hole and Jackrabbit Spring. Values are an average of pre- and post-NDS deployment $(n=2)$.

\begin{tabular}{lcc}
\hline Variable & $\begin{array}{c}\text { Devils } \\
\text { Hole }\end{array}$ & $\begin{array}{c}\text { Jackrabbit } \\
\text { Spring }\end{array}$ \\
\hline $\begin{array}{l}\text { Water temperature } \\
\quad\left({ }^{\circ} \mathrm{C}\right)\end{array}$ & 33.46 & 27.61 \\
Elevation $(\mathrm{m})$ & 833 & 833 \\
$\mathrm{pH}$ & 7.31 & 7.24 \\
$\mathrm{Dissolved} \mathrm{oxygen}$ & 3.09 & 6.02 \\
$\quad\left(\mathrm{mg} \cdot \mathrm{L}^{-1}\right)$ & & \\
$\mathrm{NO}_{3}-\mathrm{N}\left(\mathrm{mg} \cdot \mathrm{L}^{-1}\right)$ & 0.075 & 0.003 \\
$\mathrm{PO}_{4}-\mathrm{P}\left(\mathrm{mg} \cdot \mathrm{L}^{-1}\right)$ & 0.002 & 0.005 \\
$\mathrm{~N}: \mathrm{P}$ & 30.8 & 0.7 \\
$\mathrm{SO}$ & 89.6 & 103.5 \\
$\mathrm{Cl}\left(\mathrm{mg} \cdot \mathrm{L}^{-1}\right)$ & 23.8 & 26.2 \\
\hline
\end{tabular}

2001). Thus, factors limiting microbial biofilm growth can affect whole ecosystem dynamics and potentially shift microbial community structure between autotrophic and heterotrophic growth (Hoellein et al. 2010).

Little is known about microscale biofilm heterogeneity and nutrient cycling in desert springs; however, the biodiversity found in these ecosystems is endangered by groundwater exploitation and anthropogenic activities (Sada and Vinyard 2002). Desert springs in the southwestern U.S. provide critical habitat for dozens of endemic species of plants and animals as well as threatened or endangered species (Shepard et al. 2000). Because of the vital role basal resources (algae and benthic microbes) play in maintaining a suitable environment for surrounding organisms, a more comprehensive understanding is needed of how biofilm dynamics influence ecosystem processes in southwestern desert springs. Understanding desert freshwater ecosystems in the American Southwest is especially important because of the projected regional climate change (Seager et al. 2007, Diffenbaugh et al. 2008). Specifically, increased aridity and fewer but more intense precipitation events may have important implications to aquatic desert ecosystems as solar radiation to aquatic ecosystems increases, with fewer precipitation events and decreased cloud cover. Our limited understanding of desert freshwater biofilm function limits our ability to successfully predict responses to anthropogenically induced environmental change.

The objectives of this study were to (1) quantify the spatial and temporal variability of microbial biofilm physicochemical characteristics in Devils Hole, Nevada, and (2) quantify nutrient limitation of autotrophic and heterotrophic microbial biofilms in desert springs. We hypothesized that physicochemical characteristics would have distinct diurnal and seasonal trends that differ among autotrophic and heterotrophic biofilms. Additionally, we hypothesized that autotrophic microbial activity (as photosynthesis) in desert springs would be nitrogen and phosphorus co-limited; whereas heterotrophic activity (as respiration) would be primarily limited by sulfide.

\section{Methods}

\section{Study Sites}

Devils Hole is a detached component of Death Valley National Park, located in Ash Meadows National Wildlife Refuge, Nye County, Nevada, USA $\left(36^{\circ} 26^{\prime} \mathrm{N}, 116^{\circ} 17^{\prime} \mathrm{W}\right)$. Physicochemical parameters of Devils Hole were previously characterized by Gustafson and Deacon (1998) and Wilson and Blinn (2007). Briefly, the water surface of Devils Hole is approximately $15 \mathrm{~m}$ below ground level $(833 \mathrm{~m}$ elevation) and measures $22 \mathrm{~m}$ long by $3.5 \mathrm{~m}$ wide. The northwest end of Devils Hole has a pool extending to an unknown depth $(>150 \mathrm{~m})$. The southeast end of Devils Hole has a "shallow shelf" $6.1 \mathrm{~m}$ long, $2.6 \mathrm{~m}$ wide, and $0-1 \mathrm{~m}$ deep. This ecosystem receives $4-5 \mathrm{~h}$ direct light in the summer and no direct light from December to January. Bulk water temperature in Devils Hole consistently averages $33.5^{\circ} \mathrm{C}$, with approximately $1{ }^{\circ} \mathrm{C}$ summer fluctuation associated with diel variation in light (Gustafson and Deacon 1998, Wilson and Blinn 2007). Bulk water oxygen is low, averaging $3.6 \pm 0.2 \mathrm{mg}$ $\mathrm{O}_{2} \cdot \mathrm{L}^{-1}$ (Gustafson and Deacon 1998, Wilson and Blinn 2007).

For nutrient limitation experiments, we compared Devils Hole to Jackrabbit Spring which is also located in Ash Meadows National Wildlife Refuge, $<5 \mathrm{~km}$ from Devils Hole. Jackrabbit Spring has a spring pool with a restored outflow stream. It is surrounded by grasses, has no canopy cover, and is exposed to approximately $10 \mathrm{~h}$ of direct light in summer. Devils Hole is a window into the regional groundwater system, whereas Jackrabbit Spring is a discharge point from this groundwater system into a pool with low sedimentation rates and similar water chemistry 
(Table 1; Winograd and Pearson 1976). Common algal and filamentous cyanobacteria species in these desert springs include Lyngbya, Oscillatoria, and Spirogyra (Shepard et al. 2000).

Microbial biofilms are the dominant source of carbon for these desert spring ecosystems, particularly in the summer; however, additional allochthonous carbon inputs from terrestrial plants, insects, and mammal feces contribute to the ecosystem (Wilson and Blinn 2007). Algal biomass peaks between July and August; while in February, autotrophic biomass is minimal (James 1969). Significant spatial variation in biofilm types was observed throughout the study period (i.e., each biofilm type was found throughout the study area).

\section{Descriptive Sampling}

Descriptive sampling was conducted in Devils Hole over 1 year, with 6 sampling events (August, October, and December 2011; March, April, and July 2012). At each sampling event, microelectrodes were used to measure bulk water and pore water nutrient concentrations in addition to biofilm oxygen, $\mathrm{pH}$, sulfide, and temperature. Pore water and microelectrode measurements were separated based on biofilm type (see below). During sampling events where the shallow shelf received direct light (August, October, March, April, and July), measurements were conducted during both indirect light (8:00-13:00) and direct light (13:00-15:00) periods. Biofilm sampling for composition and biomass were conducted within 3 weeks of nutrient and physiochemical measurements in conjunction with National Park Service sampling efforts.

\section{Nutrient Concentrations}

Bulk water and pore water samples were collected to measure nutrient concentrations at each sampling event $(n=6)$. Four replicate bulk water samples were collected from the vertical center of the water column at 4 points along a transect across the shallow shelf. Three pore water samples were collected from $1 \mathrm{~cm}$ below the biofilm surface in each biofilm type present. Specifically, the tip of a $5-\mathrm{mL}$ syringe was placed into the biofilm and water was extracted by suction. All water samples were immediately filtered through a $25-\mathrm{mm}$ Whatman ${ }^{\circledR}$ glass microfiber filter (nominal pore size $0.7 \mu \mathrm{m})$, stored in an acid-washed Nalgene bottle on ice, and frozen within $6 \mathrm{~h}$ for subsequent nutrient analyses. Ammonium $\left(\mathrm{NH}_{4}\right)$, sulfate $\left(\mathrm{SO}_{4}\right)$, phosphate $\left(\mathrm{PO}_{4}\right)$, and nitrate $\left(\mathrm{NO}_{3}\right)$ concentrations were measured on a Dionex ion chromatograph using standard methods (DIONEX ICS-3000; Eaton et al. 2005). Ion concentrations below detection were designated as 0 in calculations: $13 \%$ of pore water samples and $4 \%$ of bulk water samples were below detection. Detection limits were $0.005 \mathrm{mg} \cdot \mathrm{L}^{-1} \mathrm{NH}_{4}, 0.03 \mathrm{mg} \cdot \mathrm{L}^{-1} \mathrm{SO}_{4}$, $0.01 \mathrm{mg} \cdot \mathrm{L}^{-1} \mathrm{PO}_{4}$, and $0.01 \mathrm{mg} \cdot \mathrm{L}^{-1} \mathrm{NO}_{3}$.

\section{Microelectrode Measurements}

Measurements of in situ biofilm temperature (TP-N), pH (pH-N), dissolved oxygen $(\mathrm{OX}-\mathrm{N})$, and sulfide $\left(\mathrm{H}_{2} \mathrm{~S}-\mathrm{N}\right)$ dynamics were conducted using Clark-type microelectrodes (Unisense, Aarhus N, Denmark; Revsbech and Jørgensen 1986, Jeroschewski et al. 1996, Bernot and Wilson 2012). During the 6 sampling events in Devils Hole, 97 temperature, $101 \mathrm{pH}, 111 \mathrm{O}_{2}$, and $99 \mathrm{H}_{2} \mathrm{~S}$ microelectrode biofilm profiles were measured. Microelectrodes were calibrated within $3 \mathrm{~d}$ prior to and following each sampling event. Temperature microelectrodes were calibrated with an 8point calibration curve developed with microelectrode response $(\mathrm{mV})$ and measurements from a handheld temperature meter (YSI, DO200). Three buffer solutions (4.01, 7.00, and 10.02) were used to calibrate the $\mathrm{pH}$ microelectrodes, and $\mathrm{mV}$ response was compared to a handheld $\mathrm{pH}$ meter measurement (Extech, pH200). Oxygen microelectrodes were calibrated using a 3-point calibration curve derived from microelectrode response $(\mathrm{mV})$ and oxygen concentrations $\left(\mathrm{mg} \mathrm{O}_{2} \cdot \mathrm{L}^{-1}\right)$ measured using Winkler titrations (Winkler 1888, Bryan et al. 1976). Sulfide microelectrodes were calibrated by generating a 5-point calibration curve from microelectrode response $(\mathrm{mV})$ and nominal sulfide concentrations made with concentrated sulfide $\left(0-10 \mathrm{mg} \cdot \mathrm{L}^{-1} \mathrm{NaS}\right.$ * $\left.9 \mathrm{H}_{2} \mathrm{O}\right)$ dissolved in pH 2.00 buffer saturated with $\mathrm{N}_{2}$ gas. Sulfide concentrations were verified via spectrophotometric measurement of calibration solutions (Cline 1969). The spectrophotometric-verified calibration was applied to all sampling events, while the calculated sulfide concentration calibrations performed before and after each sampling event confirmed consistent sulfide calibration. Calibration curves created by linear regression described the relationship between 
microelectrode response and concentration with an $r^{2} \geq 0.9$.

Temperature $\left({ }^{\circ} \mathrm{C}\right), \mathrm{pH}$, dissolved oxygen $\left(\mathrm{O}_{2}\right)$, and sulfide $\left(\mathrm{H}_{2} \mathrm{~S}\right)$ biofilm depth profiles were collected simultaneously using a custom 4-way microelectrode clamp on an extender rod attached to a Unisense micromanipulator. For each biofilm profile, a bulk water reading was recorded initially with microelectrodes submerged in bulk water $>10 \mathrm{~cm}$ above the biofilm. Corresponding bulk water readings from handheld temperature, $\mathrm{pH}$, and $\mathrm{O}_{2}$ meters were collected to monitor for microelectrode drift and to assess potential matrix effects. Throughout the study period, drift correction was needed only once for October $\mathrm{pH}$ measurements. This correction was applied by using both calibration and bulk water data. The $r^{2}$ value was $>0.9$ for the corrected calibration. No other microelectrodes displayed drift or matrix effects, and thus no corrections were applied to other calibration curves. Following bulk water measurements, each microelectrode was positioned approximately $5 \mathrm{~mm}$ above the biofilm. Descending measurements were collected every millimeter until the microelectrode reached bedrock or the maximum 38-mm depth. Microelectrode data collected in $\mathrm{mV}$ were converted to $\mathrm{mg} \cdot \mathrm{L}^{-1}$ using the calibration data from both pre- and postsampling calibration curves for temperature, $\mathrm{pH}$, and $\mathrm{O}_{2}$ microelectrodes as well as calibration data from the spectrophotometric sulfide calibration curve.

\section{Biofilm Identification}

Three primary biofilm types were identified in Devils Hole (defined as dominant group): Spirogyra, filamentous cyanobacteria (Oscillatoria and Plectonema, referred to hereafter as cyanobacteria), and Beggiatoa. The biofilms overlay hard substrata and inorganic sediment. At each sampling event $(n=6)$, a representative sample of each biofilm type was collected by cutting off approximately 1 $\mathrm{cm}^{3}$ biofilm for preservation in $1 \%$ Lugol's iodine solution. Samples were transported to Ball State University and identified with an EVOS digital inverted microscope (AMG, EVOSfl 4302). Samples collected in October deteriorated in quality before identification and are not included in analyses. Three replicates of each sample were placed on a slide, and 20 quadrats were selected using a random number generator and were measured for calculation of percent biofilm type as

Biofilm $(\%)=100 \times \frac{\text { No. of quadrants with biofilm }}{\text { No. of quadrants of all biofilm types }}$.

\section{Biofilm Biomass}

Biofilm biomass measurements were collected every 2 months, from Oct 1999 to Aug 2001 and again from Jun 2008 to Dec 2012 in conjunction with National Park Service monitoring efforts to measure ash-free dry mass (g AFDM $\cdot \mathrm{m}^{-2}$ ) of Spirogyra and cyanobacteria. These biomass measurements were collected within 3 weeks of nutrient sampling and microelectrode measurement from Aug 2011 to Jul 2012. Sixteen samples were collected systematically from the shallow shelf. A 10cm-diameter, cylindrical stovepipe with a foam strip on the bottom to create a seal with the substratum was placed over each collection point. A stiff-bristled brush was used to disturb and clean the substratum within the stovepipe. All suspended materials within the stovepipe, including suspended sediments, were collected with a turkey baster and placed into a container. Samples were stored on ice in the dark and transported for sorting within $48 \mathrm{~h}$ of collection. Each sample was sorted under a dissecting microscope $(10 \times)$ into the categories cyanobacteria (Oscillatoria, Plectonema) and Spirogyra. Material from each category was placed in a preweighed crucible and oven dried to constant weight $\left(60{ }^{\circ} \mathrm{C}\right)$. Dried samples were combusted at $500{ }^{\circ} \mathrm{C}$ for $1 \mathrm{~h}$ in a muffle furnace (Eaton et al. 2005). The difference in pre- and postburned mass was recorded as organic biomass of the sample.

\section{Nutrient Limitation Experiments}

We measured microbial nutrient limitation in 2 desert aquatic ecosystems using the nutrient diffusing substrata (NDS) technique (Tank et al. 2006). Nutrient diffusing substrata were constructed using $60-\mathrm{mL}$ hinged plastic cups (Poly-Cons ${ }^{\circledR}$; Madan Plastics, Crawford, $\mathrm{NJ}$ ). We filled the cups with approximately 60 $\mathrm{mL}$ of nutrient-enriched agar, topped with one of 2 different substrata for microbial growth. Fritted glass discs $(2.54-\mathrm{cm}$ diameter, $0.23-\mathrm{cm}$ thickness; Leco Corporation, St. Joseph, MI) were used to select for predominantly autotrophic growth, while cellulose sponges $(3 \mathrm{M}$ 
Corporation, St. Paul, MI) were used to select for predominantly heterotrophic growth (Tank et al. 2006). Each lid sealed the growing surface onto the agar, and a hole in the lid exposed $5.1 \mathrm{~cm}^{2}$ of substratum for biofilm growth. Four nutrient enrichment treatments and 2 controls of agar were made and then autoclaved. Agar control treatments included a thioglycollate control $\left(29 \mathrm{~g} \cdot \mathrm{L}^{-1} \mathrm{NIH}\right.$ thioglycollate broth; hereafter, TC) and a no nutrient addition control (hereafter, C). Nutrient enrichment treatments included nitrogen $(0.5$ $\mathrm{M} \mathrm{NH}{ }_{4} \mathrm{Cl}$; hereafter, $\left.\mathrm{N}\right)$, phosphate $(0.5 \mathrm{M}$ $\mathrm{KH}_{2} \mathrm{PO}_{4}$; hereafter, $\mathrm{P}$ ), nitrogen + phosphate $\left(0.5 \mathrm{M} \mathrm{NaNH}_{4}+0.5 \mathrm{M} \mathrm{KH}_{2} \mathrm{PO}_{4}\right.$; hereafter, $\mathrm{N}+\mathrm{P}$ ), and sulfide $\left(100 \mathrm{mg} \cdot \mathrm{L}^{-1} \mathrm{Na}_{2} \mathrm{~S}_{2} \mathrm{O}_{3}+\right.$ $29 \mathrm{~g} \cdot \mathrm{L}^{-1} \mathrm{NIH}$ thioglycollate broth; hereafter, $\mathrm{S})$. Agar concentration was $30 \mathrm{~g} \cdot \mathrm{L}^{-1}$ for $\mathrm{N}+\mathrm{P}$ treatment and $20 \mathrm{~g} \cdot \mathrm{L}^{-1}$ for all other treatments and controls. In this study, NDS were deployed for a maximum of $14 \mathrm{~d}$, which previous experiments have shown is a length of time with constant nutrient diffusion of $\mathrm{N}$ and P (e.g., Rugenski et al. 2008). This length of time also yielded significant biofilm growth in this study.

We created a novel $\mathrm{H}_{2} \mathrm{~S}$ treatment by developing an anoxic agar control and an anoxic $\mathrm{H}_{2} \mathrm{~S}$ treatment. To verify continuous $\mathrm{H}_{2} \mathrm{~S}$ diffusion from $\mathrm{S}$ treatments, a $\mathrm{H}_{2} \mathrm{~S}$ Clarktype microelectrode $\left(\mathrm{H}_{2} \mathrm{~S}-\mathrm{N}\right.$; Unisense, Aarhus $\mathrm{N}$, Denmark) was used to measure agar $\mathrm{H}_{2} \mathrm{~S}$ concentration at $4 \mathrm{~mm}$ depth into the agar. Agar made with $100 \mathrm{mg} \cdot \mathrm{L}^{-1} \mathrm{Na}_{2} \mathrm{~S}_{2} \mathrm{O}_{3}+29 \mathrm{~g}$. $\mathrm{L}^{-1} \mathrm{NIH}$ thioglycollate broth had $5.16 \mathrm{mg}$ $\mathrm{H}_{2} \mathrm{~S} \cdot \mathrm{L}^{-1}$ after $1 \mathrm{~d}$ and $2.53 \mathrm{mg} \mathrm{H}_{2} \mathrm{~S} \cdot \mathrm{L}^{-1}$ after $6 \mathrm{~d}$ when stored in the refrigerator and exposed to oxygenated air. After deployment for $14 \mathrm{~d}$, agar had $27.2 \mathrm{mg} \mathrm{H}_{2} \mathrm{~S} \cdot \mathrm{L}^{-1}$. Thioglycollate control agar had no detectable $\mathrm{H}_{2} \mathrm{~S}$ prior to deployment and $13.1 \mathrm{mg} \mathrm{H}_{2} \mathrm{~S} \cdot \mathrm{L}^{-1}$ after deployment for $14 \mathrm{~d}$.

Nutrient diffusing substrata were deployed during periods of maximum productivity at each site, from 2 July to 16 July 2012 . At each site (Devils Hole and Jackrabbit Spring), 5 replicates of each control and treatment were deployed ( $n=90$ NDS per site). NDS were randomly attached to L-bars (17 NDS per Lbar) with cable ties and anchored to the benthos approximately $15 \mathrm{~cm}$ below the water surface. Upon retrieval, samples were immediately wrapped in aluminum foil and stored on ice before being returned to the laboratory.
During the nutrient limitation experiments, spring temperature measurements were logged every 15 min throughout the NDS deployment (HOBO Water Temp Pro v2). Additionally, bulk water dissolved oxygen $\left(\mathrm{O}_{2}\right)$ and $\mathrm{pH}$ were measured at the beginning and end of the incubation period using handheld meters. Upon NDS retrieval, duplicate water samples were collected from Devils Hole and Jackrabbit Spring to measure nutrient concentrations as above. Water chemistry of the desert sites was consistent through time because of constant groundwater input from the underground carbonate aquifer (Winograd and Pearson 1976). Upon retrieval of the NDS, the established biofilm appeared similar to the biofilms growing in the surrounding natural habitat.

For autotrophic substrata (i.e., glass discs), half of the glass discs were measured for chlorophyll $a$, and the remaining glass discs were used to measure ash-free dry mass (AFDM) following NDS incubation. Chlorophyll $a$ samples were collected and immediately placed on ice. In Devils Hole, loosely attached algae growing above substrata were syringed out before removing NDS from the water. The syringed algae was filtered onto glass-fiber filters (Whatman $47 \mathrm{GF} / \mathrm{F}$, Whatman Inc., Piscataway, NJ) with a $0.7-\mu \mathrm{m}$ nominal pore size immediately upon collection at the field site and then frozen for subsequent analysis. The glass-fiber filter was added to the glass disc for chlorophyll $a$ extraction. In Jackrabbit Spring, algae were firmly attached to glass discs, and no additional collection procedures were necessary. Chlorophyll $a$ concentrations of samples on glass discs and filters were measured via hot ethanol extraction (Biggs and Kilroy 2000). Under dimmed lighting, frozen samples were thawed and submerged in $10 \mathrm{~mL}$ of $95 \%$ ethanol in a $60-\mathrm{mL}$ falcon tube. The sample was then placed in a hot water bath $\left(79{ }^{\circ} \mathrm{C}\right)$ for 5 min. Samples were extracted for $24 \mathrm{~h}$ in a refrigerator, and supernatant was measured with a spectrophotometer (UV-1700 PharmaSpec, Shimadzu) at $750 \mathrm{~nm}$ and $664 \mathrm{~nm}$. Samples were acidified with $0.1 \mathrm{~mL}$ of $0.1 \mathrm{~N} \mathrm{HCl}$ and agitated. After $90 \mathrm{~s}$, the samples were read at $750 \mathrm{~nm}$ and 664 $\mathrm{nm}$ to correct for pheophytin. For ash-free dry mass (AFDM), biofilms grown on glass discs were dried at $70{ }^{\circ} \mathrm{C}$ to a constant mass, brought to room temperature in a desiccator, 
and weighed then combusted for $1 \mathrm{~h}$ at 500 ${ }^{\circ} \mathrm{C}$. Ashed samples were rewetted with deionized water, dried at $70{ }^{\circ} \mathrm{C}$ to a constant mass, brought to room temperature in a desiccator, and weighed (Eaton et al. 2005).

For heterotrophic substrata (i.e., cellulose sponges), microbial respiration of each NDS treatment and control substratum was measured using dehydrogenase activity (DHA) assays (Trevors 1984, Bunch and Bernot 2011). Specifically, within $24 \mathrm{~h}$ of NDS collection, $15-\mathrm{mL}$ falcon tubes were filled with half of an NDS sponge fully colonized with biofilm, 2.5 $\mathrm{mL}$ of refrigerated water from the experimental site, and $1 \mathrm{~mL} 0.75 \%$ iodonitroetrazolium (INT) chloride. Desert samples were inverted 10 times until well mixed. Samples were then incubated at in situ temperatures (Table 1) for $3 \mathrm{~h}$. To stop the reaction, $8 \mathrm{~mL}$ of methanol was added, and desert samples were immediately inverted 10 times and settled. Supernatant was spectrophotometrically analyzed at $428 \mathrm{~nm}$ (UV-1700 PharmaSpec, Shimadzu). Formazan concentration was calculated with a standard curve obtained by using INT-formazan and was subsequently converted to $\mathrm{mg}$ of dissolved oxygen, where every $2 \mathrm{~mol}$ of INT-formazan produced $1 \mathrm{~mol}$ of $\mathrm{O}_{2}$ consumed in the following equation:

$$
\frac{\text { mg INT-formazan }}{1000 \times 471.25 \times 2} \times 31.99=\mathrm{mg} \mathrm{O}_{2} \text { consumed } .
$$

The mass of the other half of each sponge was used to calculate the microbial respiration as mg $\mathrm{O}_{2} \cdot \mathrm{gdm}^{-1} \mathrm{~h}^{-1}$ by drying the sample at $70{ }^{\circ} \mathrm{C}$ for $24 \mathrm{~h}$.

\section{Calculations and Statistics}

The independent variables of interest were light type, biofilm type, and sample month. Dependent variables of interest were biofilm abundance, biofilm biomass, physiochemical characteristics, and nutrient concentration. Biofilm biomass change over time was assessed using linear regression. Differences in biomass, bulk and pore water nutrient concentration, maximum $\mathrm{O}_{2}$, and maximum $\mathrm{H}_{2} \mathrm{~S}$ due to light type, biofilm type, and sample month were assessed with analysis of variance (ANOVA). Differences between phototrophic biofilms and Beggiatoa were determined using $t$ tests. All statistics were performed to identify relationships and interactions between the independent variables with $\alpha=0.05$. If there were nonsignificant interactions in 2- and 3way ANOVAs, the ANOVA was rerun with only significant interactions.

For the nutrient limitation experiments, ANOVA followed by Tukey's post hoc test was performed to identify relationships and interactions between the independent variables (treatments and controls) with $\alpha=0.05$. Twoway ANOVA was also performed using the presence of $\mathrm{N}$ or $\mathrm{P}$ as factors to assess nutrient limitation. If the residuals of the data were not normally distributed by a Shapiro-Wilk test, the data were log transformed before analysis (chlorophyll $a$ in Jackrabbit Spring and all DHA data were log transformed). Comparison of respiration rates between sample locations was nonnormal and therefore compared using Kruskal-Wallis nonparametric ANOVA with Wilcoxon's signed-ranks post hoc test. If $\mathrm{N}$ or $\mathrm{P}$ individually resulted in a significant response, there was a single-nutrient limitation. If the $\mathrm{N}$ and $\mathrm{P}$ individual responses were significant or the $\mathrm{N}$ and $\mathrm{P}$ interaction term and the $\mathrm{N}$ and $\mathrm{P}$ individual responses were significant, there was a colimitation. If the $\mathrm{N}$ and $\mathrm{P}$ interaction term and the $\mathrm{P}$ individual response were significant, there was a primary $\mathrm{P}$ limitation and secondary $\mathrm{N}$ limitation. If there were no significant relationships, biofilm responses were not nutrient limited. All statistical analyses were performed using the R 2.14.1 statistical package (R Development Core Team 2011).

\section{RESUlTs}

\section{Biofilm Identification and Biomass}

Biofilm samples were identified in the field based on appearance and verified in the laboratory by microscopic identification of percent biofilm-type composition (Fig. 1). Spirogyra biofilm samples indicated biofilms were composed of $>60 \%$ Spirogyra cells. Other constituents of Spirogyra mats across all sampling events include an average of $24 \%$ cyanobacteria, <1\% Beggiatoa, and 8\% other (diatoms, nonfilamentous cyanobacteria, detritus, and invertebrates). Biofilms categorized as cyanobacteria ranged from $21 \%$ to $90 \%$ cyanobacteria cells, with other constituents across all sampling events including an average of $12 \%$ Spirogyra, $<1 \%$ Beggiatoa, and $21 \%$ other. Beggiatoa biofilm types ranged from $30 \%$ to 

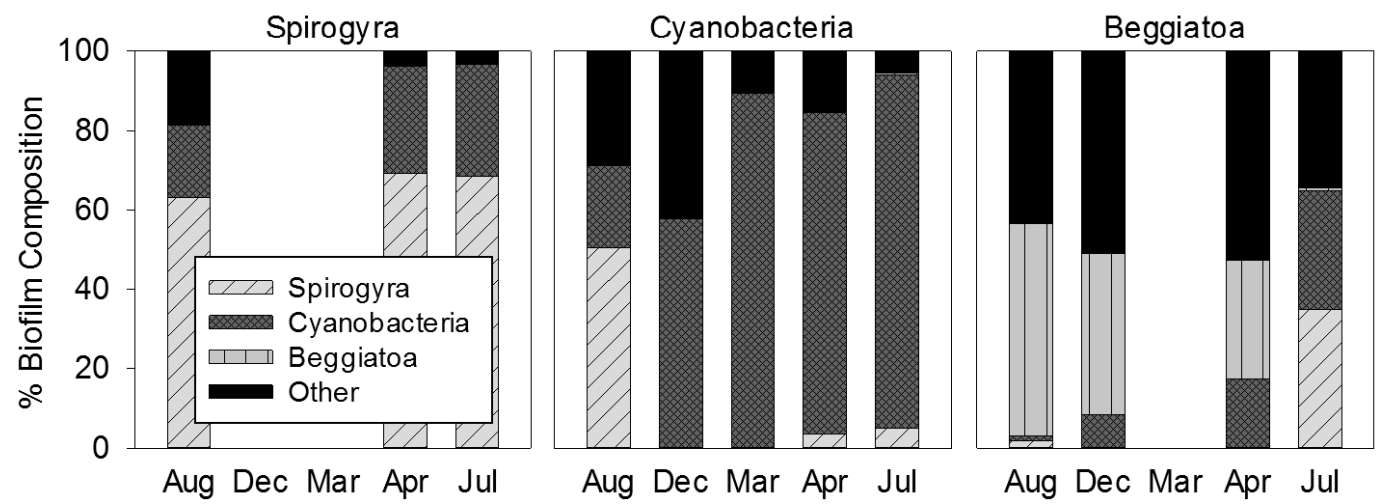

Fig. 1. Mean percent cell composition of representative samples collected in Devils Hole, Nevada, from Aug 2011 to July 2012 for each biofilm type. "Other” consisted of diatoms, nonfilamentous cyanobacteria, detritus, and other organisms. $N=60$ for each bar. Spirogyra biofilms were not present in December 2011 and March 2012; Beggiatoa biofilms were not present in March 2012.

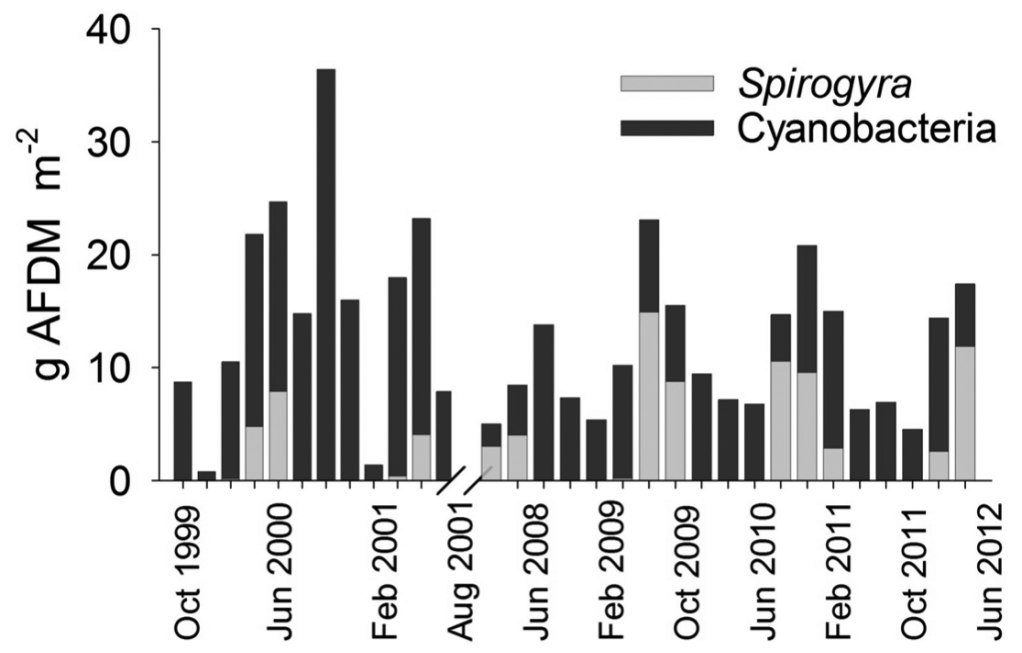

Fig. 2. Spirogyra and cyanobacteria biofilm biomass (AFDM $\cdot \mathrm{m}^{-2}$ ) in Devils Hole from 1999 to 2001 and 2008 to 2012. Biomass of cyanobacteria decreased over the sampling period. Data collected by the National Park Service.

$54 \%$ Beggiatoa cells, with other constituents across all sampling events including an average of $9 \%$ Spirogyra, 14\% cyanobacteria, and $45 \%$ other.

Overall, Spirogyra biomass in Devils Hole did not change from 1999 to 2012 (Fig. 2); however, the Spirogyra biomass varied among months: it was abundant in June and absent in December and February $\left(F_{5,34}=8.294, P<\right.$ $0.001)$. In contrast, cyanobacteria biomass significantly decreased over time, from 1999 to $2012\left(r^{2}=0.173, F_{1,38}=7.952, P=0.008\right)$, but did not vary among months.

\section{Devils Hole Nutrient Concentrations}

Pore water and bulk water $\mathrm{SO}_{4}$ and $\mathrm{NO}_{3}$ concentrations varied less over the study period relative to $\mathrm{PO}_{4}$ concentrations (Tables $2,3)$. Across sampling events, mean bulk water $\mathrm{SO}_{4}$ ranged from 22.87 to $91.55 \mathrm{mg} \cdot \mathrm{L}^{-1}$. In pore water, mean $\mathrm{SO}_{4}$ concentration ranged from 15.32 to $81.73 \mathrm{mg} \cdot \mathrm{L}^{-1}$ in Spirogyra, 16.36 to $87.74 \mathrm{mg} \cdot \mathrm{L}^{-1}$ in cyanobacteria, and 20.11 to $79.54 \mathrm{mg} \cdot \mathrm{L}^{-1}$ in Beggiatoa. Mean bulk water $\mathrm{PO}_{4}$ ranged from below detection to $4.52 \mathrm{mg} \cdot \mathrm{L}^{-1}$. In pore water, mean $\mathrm{PO}_{4}$ concentration ranged from below detection to 
TABLE 2. Mean bulk water $\mathrm{SO}_{4}, \mathrm{PO}_{4}$, and $\mathrm{NO}_{3}$ concentration $\left(\mathrm{mg} \cdot \mathrm{L}^{-1}\right)$ collected bimonthly in Devils Hole, Nevada, August 2011 to July 2012. Values are means with standard deviations in parentheses ( $N=4$ for each sample). Bulk water $\mathrm{NH}_{4}$ was below detection in all samples. Missing sample dates are blank. Concentrations below detection limits are indicated by an asterisk (*).

\begin{tabular}{|c|c|c|c|c|c|c|}
\hline \multirow[b]{2}{*}{ Month } & \multicolumn{3}{|c|}{ Direct light } & \multicolumn{3}{|c|}{ Indirect light } \\
\hline & $\mathrm{SO}_{4}$ & $\mathrm{PO}_{4}$ & $\mathrm{NO}_{3}$ & $\mathrm{SO}_{4}$ & $\mathrm{PO}_{4}$ & $\mathrm{NO}_{3}$ \\
\hline August & $84.9(1.0)$ & $*$ & $0.1(<0.0)$ & $85.0(2.4)$ & $*$ & $0.1(<0.0)$ \\
\hline October & $90.9(0.6)$ & $*$ & $0.2(<0.0)$ & $91.6(0.3)$ & $*$ & $0.2(<0.0)$ \\
\hline December & & & & $89.5(1.5)$ & $*$ & $0.3(<0.0)$ \\
\hline March & $32.8(2.8)$ & $0.4(0.2)$ & $0.4(<0.0)$ & $27.1(2.9)$ & $0.9(0.3)$ & $0.4(<0.0)$ \\
\hline April & $22.9(1.4)$ & $4.5(1.7)$ & $0.5(<0.0)$ & $28.4(1.5)$ & $0.8(0.3)$ & $0.5(<0.0)$ \\
\hline July & $89.6(0.2)$ & * & $0.1(<0.0)$ & $87.7(1.3)$ & $0.01(<0.0)$ & $0.1(<0.0)$ \\
\hline
\end{tabular}

$5.51 \mathrm{mg} \cdot \mathrm{L}^{-1}$ in Spirogyra, below detection to $3.45 \mathrm{mg} \cdot \mathrm{L}^{-1}$ in cyanobacteria, and below detection to $1.72 \mathrm{mg} \cdot \mathrm{L}^{-1}$ in Beggiatoa. Bulk water mean $\mathrm{NO}_{3}$ ranged from 0.07 to $0.53 \mathrm{mg}$. $\mathrm{L}^{-1}$. In pore water, mean $\mathrm{NO}_{3}$ concentration ranged from below detection to $0.25 \mathrm{mg} \cdot \mathrm{L}^{-1}$ in Spirogyra, below detection to $0.32 \mathrm{mg} \cdot \mathrm{L}^{-1}$ in cyanobacteria, and below detection to 0.41 $\mathrm{mg} \cdot \mathrm{L}^{-1}$ in Beggiatoa. Bulk water $\mathrm{NH}_{4}$ was below detection in all samples. In pore water, mean $\mathrm{NH}_{4}$ concentration ranged from below detection to $0.17 \mathrm{mg} \cdot \mathrm{L}^{-1}$ in Spirogyra, from below detection to $0.7 \mathrm{mg} \cdot \mathrm{L}^{-1}$ in cyanobacteria, and from below detection to $0.58 \mathrm{mg} \cdot \mathrm{L}^{-1}$ in Beggiatoa. There were no significant differences in $\mathrm{NH}_{4}$ concentration between bulk and pore water samples.

Differences in $\mathrm{SO}_{4}$ concentration were found with light type, biofilm type, and sample month (Tables 2, 3). Bulk water $\mathrm{SO}_{4}$ concentration had an interaction between light and sample month $\left(F_{4,33}=3.4, P=0.042\right)$. Specifically, the effect of light was reduced in the fall and winter, consistent with reduced light exposure. Pore water $\mathrm{SO}_{4}$ concentration also varied by light type and sample month. In pore water, there was an interaction between light and biofilm type $\left(F_{2,41}=3.4, P=0.042\right)$, where $\mathrm{SO}_{4}$ concentrations were $20 \%$ lower in direct light $\left(\bar{x}=46.8 \mathrm{mg} \cdot \mathrm{L}^{-1}\right)$ than in indirect light $\left(\bar{x}=56.9 \mathrm{mg} \cdot \mathrm{L}^{-1}\right)$. Differences in $\mathrm{SO}_{4}$ concentration by biofilm type indicated Beggiatoa $\left(\bar{x}=60.4 \mathrm{mg} \cdot \mathrm{L}^{-1}\right) \mathrm{SO}_{4}$ concentrations were $22.6 \%$ higher than cyanobacteria $\mathrm{SO}_{4}$ concentrations and $19.5 \%$ higher than Spirogyra $\mathrm{SO}_{4}$ concentrations $(\bar{x}=49.7 \mathrm{mg}$. $\left.\mathrm{L}^{-1}\right)$. Furthermore, there was an interaction between light type and sample month, where Spirogyra varied most in response to light type and sample month $\left(F_{4,41}=5.9, P=\right.$ $0.001)$, with differences in light type yielding the largest difference in $\mathrm{SO}_{4}$ concentration during summer.

Bulk water $\mathrm{PO}_{4}$ concentrations had an interaction between light and sample month $\left(F_{4,33}=5.4, P=0.002\right.$; Table 2$)$, where direct light during spring had higher $\mathrm{PO}_{4}$ concentrations than indirect light. In pore water, $\mathrm{PO}_{4}$ concentration did not differ among biofilm types or light type (Table 3); however, it did vary by sample month. Pore water $\mathrm{PO}_{4}$ was measured at highest concentrations in April $\left(\bar{x}=2.8 \mathrm{mg} \cdot \mathrm{L}^{-1}\right)$ and was $200 \%$ higher at that time than in August $\left(\bar{x}<0.1 \mathrm{mg} \cdot \mathrm{L}^{-1}\right.$; $\left.F_{5,31}=8.5, P<0.001\right)$.

Concentrations of $\mathrm{NO}_{3}$ did not differ between direct and indirect light exposure (Tables 2, 3). Differences in $\mathrm{NO}_{3}$ concentrations were identified with sample month in bulk water (Table 2). April had the highest $\mathrm{NO}_{3}$ concentration $\left(\bar{x}=0.5 \mathrm{mg} \cdot \mathrm{L}^{-1}\right)$, which was $152 \%$ higher than $\mathrm{NO}_{3}$ concentrations in August $\left(\bar{x}=0.1 \mathrm{mg} \cdot \mathrm{L}^{-1} ; F_{5,31}=502, P<\right.$ 0.001). Pore water $\mathrm{NO}_{3}$ concentrations also varied by sample month, with March having the highest $\mathrm{NO}_{3}$ concentration $(\bar{x}=0.4 \mathrm{mg}$. $\left.\mathrm{L}^{-1}\right)$, which was $177 \%$ higher than in July $(\bar{x}<$ $0.1 \mathrm{mg} \cdot \mathrm{L}^{-1} ; F_{5,41}=8.3, P=0.001$; Table 3$)$. Pore water $\mathrm{NO}_{3}$ also varied with biofilm type: $\mathrm{NO}_{3}$ concentrations in cyanobacteria $(\bar{x}=0.2$ $\left.\mathrm{mg} \cdot \mathrm{L}^{-1}\right)$ were $67.7 \%$ higher than in Spirogyra $\left(\bar{x}=0.1 \mathrm{mg} \cdot \mathrm{L}^{-1} ; F_{3,41}=4.0, P=0.006\right)$, but there were no interactions.

\section{Devils Hole Microelectrode Measurements}

Across biofilm types, $\mathrm{O}_{2}$ concentrations were typically higher during direct light than during indirect light periods (Fig. 3). Oxygen concentrations typically increased from $0-\mathrm{mm}\left(\bar{x}=3.72 \mathrm{mg} \mathrm{O} \cdot \mathrm{L}^{-1}\right)$ to $10-\mathrm{mm}$ $\left(\bar{x}=13.75 \mathrm{mg} \mathrm{O}{ }_{2} \cdot \mathrm{L}^{-1}\right)$ depths into the biofilm during direct light (Fig. 3), though 


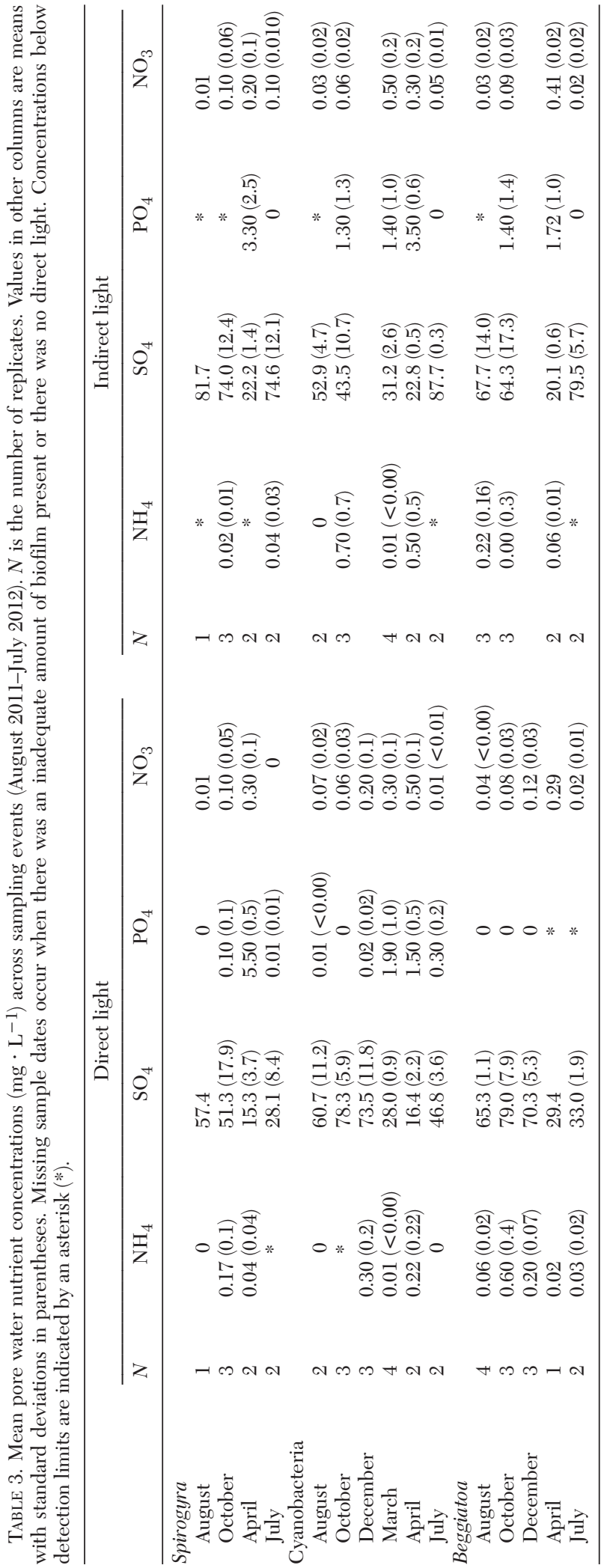



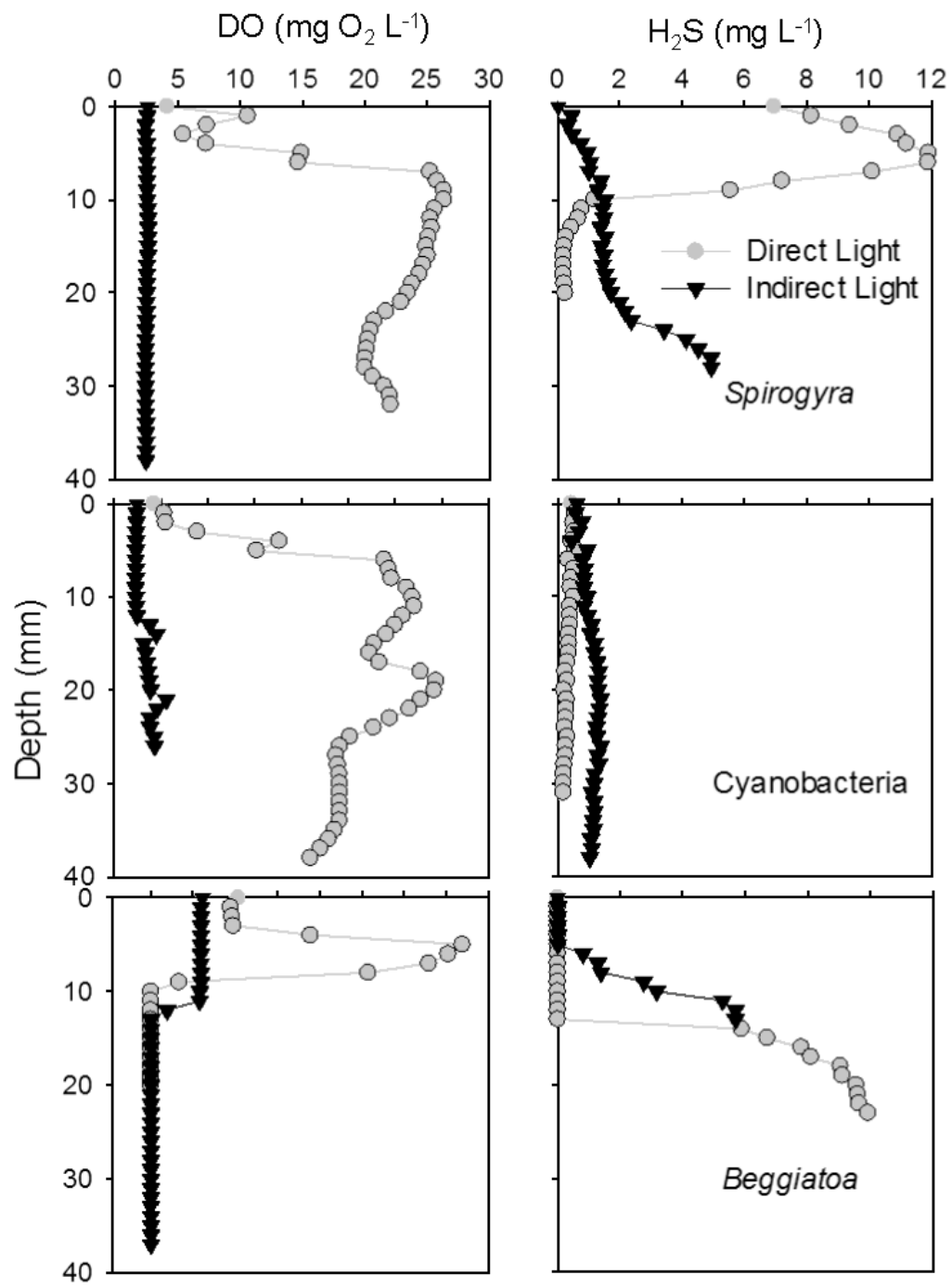

Fig. 3. Representative microelectrode profiles of dissolved oxygen $\left(\mathrm{O}_{2}\right)$ and sulfide $\left(\mathrm{H}_{2} \mathrm{~S}\right)$ concentrations $\left(\mathrm{mg} \cdot \mathrm{L}^{-1}\right)$ with depth into the benthos in 3 different microbial biofilm types: Spirogyra, Cyanobacteria, and Beggiatoa.

depth at which maximum oxygen concentrations were measured in a biofilm were highly variable. Photoautotrophic biofilms (Spirogyra, cyanobacteria) had lower mean $\mathrm{H}_{2} \mathrm{~S}$ concentrations relative to Beggiatoa biofilms $(t=5.76, P<0.001$; Fig. 3). In Beggiatoa biofilms, there was an inverse relationship between $\mathrm{O}_{2}$ and $\mathrm{H}_{2} \mathrm{~S}$ concentrations, where $\mathrm{O}_{2}$ concentration declined with depth into the biofilm and $\mathrm{H}_{2} \mathrm{~S}$ concentration increased. Increases in Beggiatoa $\mathrm{H}_{2} \mathrm{~S}$ concentration occurred at depths $>10 \mathrm{~mm}$ (Fig. 3).

Water temperatures were $3.9 \%$ greater in direct light $\left(\bar{x}=33.0^{\circ} \mathrm{C}\right)$ than in indirect light $\left(\bar{x}=31.7{ }^{\circ} \mathrm{C} ; F_{1,95}=13.5, P<0.001 ;\right.$ Table 4). There was no significant difference in mean biofilm temperature among biofilm types. Mean biofilm $\mathrm{pH}$ ranged from 7.26 to 8.03 across sampling events. The $\mathrm{pH}$ was $4.7 \%$ greater in water receiving direct light (mean $\mathrm{pH}=7.73$ ) than in water receiving indirect light (mean $\mathrm{pH}=7.37 ; F_{1.102}=7.91$, $P=0.006$; Table 4). Mean biofilm $\mathrm{pH}$ was not significantly different among biofilm types. Further, pH change with biofilm depth was highly variable among depth profiles and not specific to biofilm types (data not shown). 
TABLe 4. Temperature (Temp; ${ }^{\circ} \mathrm{C}$ ) and $\mathrm{pH}$ in Devils Hole, Nevada, across sampling events (August 2011-July 2012) and separated by biofilm type. $N$ is the number of replicates. Values in other columns are means with standard deviations in parentheses. Neither temperature nor $\mathrm{pH}$ differed among biofilm types.

\begin{tabular}{lrrrrrr}
\hline & \multicolumn{7}{c}{ Biofilm type } \\
\cline { 2 - 7 } & $N$ & Spirogyra & $N$ & Cyanobacteria & $N$ & Beggiatoa \\
\hline Direct light & 12 & $32.83(0.62)$ & 17 & $33.16(0.43)$ & 4 & $32.50(1.05)$ \\
$\quad$ Temp & 12 & $8.03(0.19)$ & 13 & $7.59(0.18)$ & 12 & $7.57(0.10)$ \\
pH & 18 & $31.74(0.39)$ & 33 & $31.96(0.21)$ & 13 & $31.03(0.40)$ \\
Indirect light & 20 & $7.41(0.10)$ & 33 & $7.26(0.11)$ & 13 & $7.62(0.11)$ \\
$\quad$ Temp & & & & & & \\
pH & & &
\end{tabular}

Maximum biofilm $\mathrm{O}_{2}$ concentration was influenced by light, biofilm type, and sample month (Fig. 4). Specifically, maximum $\mathrm{O}_{2}$ concentrations in direct light $\left(\bar{x}=23.3 \mathrm{mg} \mathrm{O}_{2} \cdot \mathrm{L}^{-1}\right)$ were $127.5 \%$ greater than during indirect light $\left(\bar{x}=5.1 \mathrm{mg} \mathrm{O} \mathrm{O}_{2} \cdot \mathrm{L}^{-1}\right)$ across all biofilms $\left(F_{1,98}=\right.$ 131.8, $P<0.001)$. Cyanobacteria maximum $\mathrm{O}_{2}$ $\left(\bar{x}=13.9 \mathrm{mg} \mathrm{O} \cdot \mathrm{L}^{-1}\right)$ was $5.7 \%$ higher than Spirogyra $\left(\bar{x}=13.2 \mathrm{mg} \mathrm{O} \cdot \mathrm{L}^{-1}\right)$ and $87.0 \%$ higher than Beggiatoa $\left(\bar{x}=5.5 \mathrm{mg} \mathrm{O} \mathrm{O}_{2} \cdot \mathrm{L}^{-1}\right)$ across all light conditions and sample months $\left(F_{2,98}=9.0, P<0.001\right)$. Maximum $\mathrm{O}_{2}$ concentrations in sample months differed across light and biofilm types $\left(F_{5,98}=11.3, P<0.001\right)$. Specifically, March $\left(\bar{x}=20.0 \mathrm{mg} \mathrm{O} \cdot \mathrm{L}^{-1}\right)$ had the largest difference in $\mathrm{O}_{2}$ concentrations between direct and indirect light exposure measurements $\left(F_{4,98}=3.4, P=0.011\right)$. Maximum $\mathrm{O}_{2}$ concentration during direct light peaked in March, while maximum $\mathrm{O}_{2}$ concentration during indirect light was highest in July.

Maximum biofilm $\mathrm{H}_{2} \mathrm{~S}$ concentration was influenced by biofilm type and sample month (Fig. 4). Specifically, Beggiatoa maximum $\mathrm{H}_{2} \mathrm{~S}$ $\left(\bar{x}=11.4 \mathrm{mg} \mathrm{H}_{2} \mathrm{~S} \cdot \mathrm{L}^{-1}\right)$ was $167.2 \%$ higher than Spirogyra $\left(\bar{x}=1.2 \mathrm{mg} \mathrm{H}_{2} \mathrm{~S} \cdot \mathrm{L}^{-1}\right)$ and $167.4 \%$ higher than cyanobacteria $(\bar{x}=1.0 \mathrm{mg}$ $\mathrm{H}_{2} \mathrm{~S} \cdot \mathrm{L}^{-1}$ ) across all light types and sample months $\left(F_{2,84}=82.6, P<0.001\right)$. Across light and biofilm types, sample months differed in biofilm $\mathrm{H}_{2} \mathrm{~S}$ concentrations $\left(F_{4,84}=4.0, P=\right.$ $0.005)$. October $\left(\bar{x}=6.1 \mathrm{mg} \mathrm{H}_{2} \mathrm{~S} \cdot \mathrm{L}^{-1}\right)$ had the highest biofilm $\mathrm{H}_{2} \mathrm{~S}$ concentrations, which were $80.5 \%$ higher than July $(\bar{x}=2.6 \mathrm{mg}$ $\mathrm{H}_{2} \mathrm{~S} \cdot \mathrm{L}^{-1}$ ), the month with the lowest biofilm $\mathrm{H}_{2} \mathrm{~S}$ concentrations. Biofilm $\mathrm{H}_{2} \mathrm{~S}$ concentrations were influenced by an interaction between biofilm type and sample month $\left(F_{6,84}\right.$ $=7.4, P<0.001)$. Concentrations of $\mathrm{H}_{2} \mathrm{~S}$ peaked in Beggiatoa during summer, in cyanobacteria during March and April, and in Spirogyra during July and October.

\section{Nutrient Limitation Experiment}

Chlorophyll $a$ concentrations on autotrophic substrata (fritted glass discs) in Devils Hole and Jackrabbit Spring indicate organisms were likely nutrient limited (Table 5, Fig. $5)$. Within a site, chlorophyll $a$ concentration varied 1-2 orders of magnitude across nutrient treatments, though across sites concentrations varied $<65 \%$, suggesting nutrient availability was more influential to chlorophyll $a$ production than different sites. Mean chlorophyll $a$ concentrations were generally lower in Jackrabbit Spring (from 0.7 to $81.7 \mathrm{mg} \cdot \mathrm{m}^{-2}$ ) than in Devils Hole (from 20.5 to $53.7 \mathrm{mg}$. $\mathrm{m}^{-2}$ ). Across treatments, chlorophyll $a$ concentrations did not differ in Devils Hole $\left(F_{5,28}=\right.$ 1.3, $P>0.05)$. However, in Jackrabbit Spring, chlorophyll $a$ concentration differed among treatments $\left(F_{5,24}=47.16, P<0.001\right)$, where the $\mathrm{N}+\mathrm{P}$ treatment $\left(\bar{x}=61.5 \mathrm{mg} \cdot \mathrm{m}^{-2}\right)$ was $86.4 \%$ higher than all other treatments $(\bar{x}=$ $4.5 \mathrm{mg} \cdot \mathrm{m}^{-2}$ ).

In contrast to chlorophyll $a$ concentrations, mean microbial respiration did differ among sites. Jackrabbit Spring had higher respiration $\left(\bar{x}=0.725 \mathrm{mg} \mathrm{O}_{2} \cdot \mathrm{gdm}^{-1} \mathrm{~h}^{-1}\right)$ compared to Devils Hole $\left(\bar{x}=0.259 \mathrm{O}_{2} \cdot \mathrm{gdm}^{-1} \mathrm{~h}^{-1}\right)$, suggesting that site differences as well as nutrient concentrations may dictate heterotrophic activity (Fig. 6). Respiration in Jackrabbit Spring ranged from 0.15 to $6.71 \mathrm{mg} \mathrm{O} \cdot \mathrm{gdm}^{-1} \mathrm{~h}^{-1}$. In Devils Hole, respiration ranged from 0.04 to $1.14 \mathrm{mg} \mathrm{O}_{2} \cdot \mathrm{gdm}^{-1} \mathrm{~h}^{-1}$. Respiration data suggest that microbial organisms on cellulose sponges were nutrient limited at all sites (Fig. 6). In Devils Hole, respiration rate differed among nutrient treatments $\left(F_{4,20}=3.4, P=\right.$ 0.029 ): the anoxic TC respiration was $186 \%$ higher $\left(\bar{x}=0.54 \mathrm{mg} \mathrm{O}_{2} \cdot \mathrm{gdm}^{-1} \mathrm{~h}^{-1}\right)$ than the oxic control $\left(\bar{x}=0.14 \mathrm{mg} \mathrm{O}_{2} \cdot \mathrm{gdm}^{-1} \mathrm{~h}^{-1}\right.$; Fig. 6). Microbial respiration in Jackrabbit Spring 

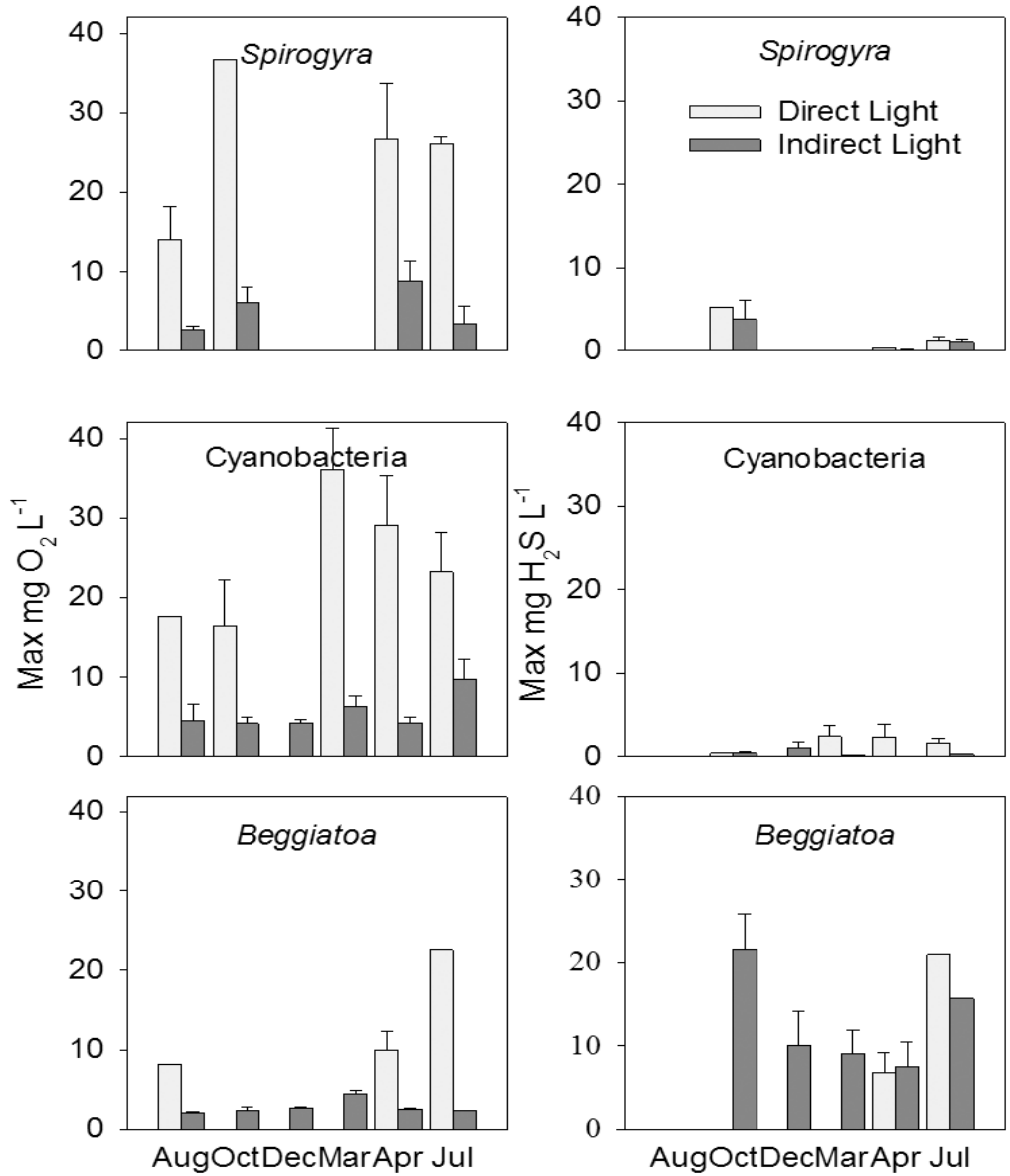

Fig. 4. Mean maximum $\mathrm{O}_{2}$ and $\mathrm{H}_{2} \mathrm{~S}$ concentration collected in 3 different biofilm types (Spirogyra, Cyanobacteria, and Beggiatoa) during direct and indirect light periods across 6 sampling events in Devils Hole, Nevada. Whisker bars represent $1 \mathrm{SE}$.

TABLE 5. Ash-free dry mass (AFDM) on diffusing substrata glass discs in Devils Hole (DH; $n=3)$ and Jackrabbit Spring (JS; $n=5)$. Values are means with SD in parentheses. Agar treatments and controls include no nutrient addition (C), thioglycollate control (TC), nitrogen (N), phosphorus $(\mathrm{P})$, nitrogen + phosphorus $(\mathrm{N}+\mathrm{P})$, and sulfide $(\mathrm{S})$.

\begin{tabular}{lcc}
\hline & \multicolumn{2}{c}{$\operatorname{AFDM}\left(\mathrm{g} \cdot \mathrm{m}^{-2}\right)$} \\
\cline { 2 - 3 } Treatment & Devils Hole & Jackrabbit Spring \\
\hline $\mathrm{C}$ & $19.7(11.6)$ & $3.2(0.5)$ \\
TC & $27.9(8.5)$ & $9.5(0.6)$ \\
$\mathrm{N}$ & $13.3(2.3)$ & $5.2(0.3)$ \\
$\mathrm{P}$ & $22.1(8.0)$ & $7.5(0.8)$ \\
$\mathrm{N}+\mathrm{P}$ & $13.2(3.7)$ & $15.6(0.9)$ \\
$\mathrm{S}$ & $14.6(3.4)$ & $15.2(1.5)$ \\
\hline
\end{tabular}

also differed in response to nutrient treatments $\left(F_{4,20}=3.8, P=0.019\right)$ : TC $(\bar{x}=2.43$ mg O $\left.{ }_{2} \cdot \mathrm{gdm}^{-1} \mathrm{~h}^{-1}\right)$ had $191 \%$ higher respiration than all other treatments $\left(\bar{x}=0.30 \mathrm{mg} \mathrm{O} \mathrm{O}_{2}\right.$. $\mathrm{gdm}^{-1} \mathrm{~h}^{-1}$; Fig. 6).

The biomass accrual was lowest in Jackrabbit Spring and ranged from 2.1 to $19.2 \mathrm{~g} \cdot \mathrm{m}^{-2}$ (Table 5). In Devils Hole, biomass accrual ranged from 3.7 to $42.3 \mathrm{~g} \cdot \mathrm{m}^{-2}$. Nutrient treatments did not influence biofilm accrual in Devils Hole $(P>0.05)$. Biofilm biomass in Jackrabbit Spring $\left(F_{5,24}=133.5, P<0.001\right)$ was $66 \%$ higher in the $\mathrm{N}+\mathrm{P}$ treatment $(\bar{x}=$ $\left.15.6 \mathrm{~g} \cdot \mathrm{m}^{-2}\right)$ than in the control treatment $(\bar{x}$ $\left.=3.2 \mathrm{~g} \cdot \mathrm{m}^{-2}\right)$. The TC $\left(\bar{x}=9.5 \mathrm{~g} \cdot \mathrm{m}^{-2}\right)$ and the $\mathrm{S}$ treatment $\left(\bar{x}=15.3 \mathrm{~g} \cdot \mathrm{m}^{-2}\right)$ also yielded higher biomass than the control treatment (Table 5).

Devils Hole respiration suggests that organisms were $\mathrm{N}$ limited and that biofilm respiration increased with the addition of $\mathrm{N}$ 

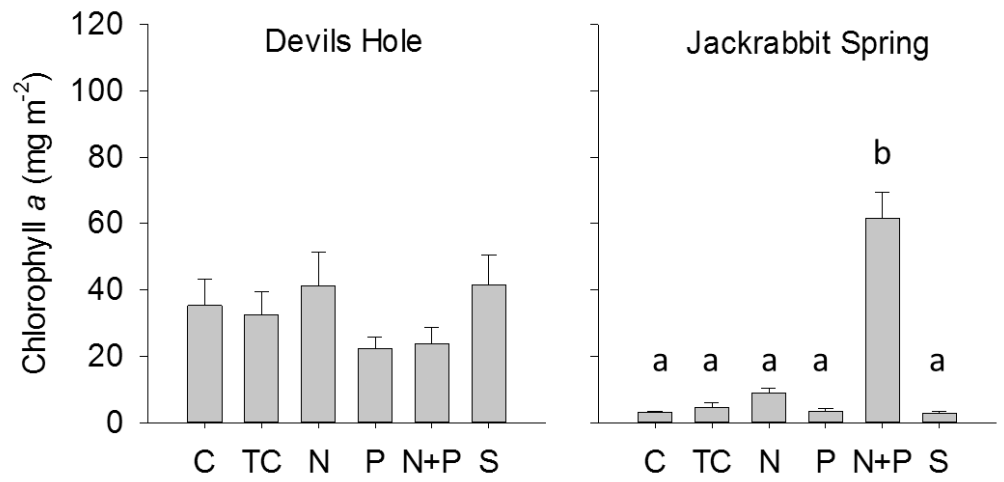

Fig. 5. Chlorophyll $a$ concentration on diffusing substrata glass discs in Devils Hole $(n=6)$ and Jackrabbit Spring $(n=5)$. Agar treatments and controls include no nutrient addition $(\mathrm{C})$, thioglycollate control (TC), nitrogen $(\mathrm{N})$, phosphorus $(\mathrm{P})$, nitrogen + phosphorus $(\mathrm{N}+\mathrm{P})$, and sulfide $(\mathrm{S})$. Bars represent mean values, and whisker bars represent $1 \mathrm{SE}$. Letters refer to ANOVA comparison between controls and treatments where the same letters are not significantly different (ANOVA: $P<0.05$ ).
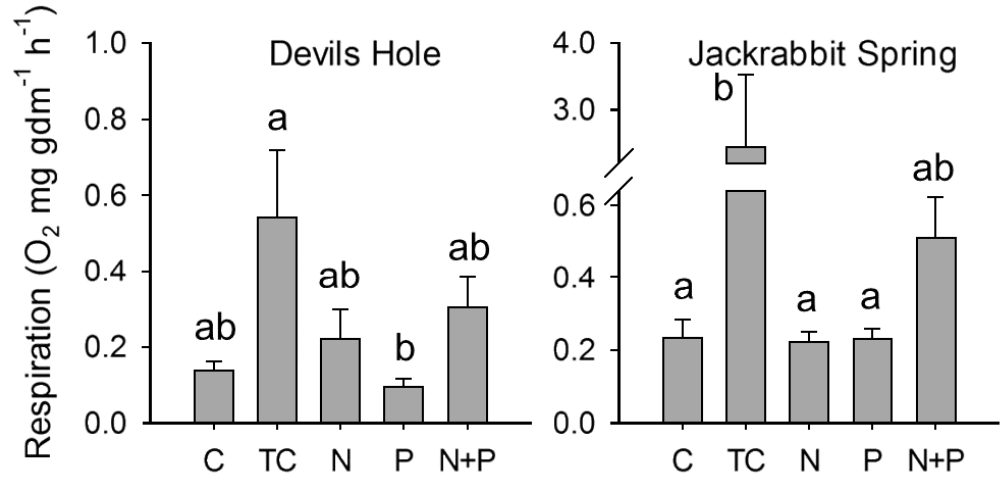

Fig. 6. Microbial respiration on diffusing substrata cellulose sponges in Devils Hole $(n=5)$ and Jackrabbit Spring $(n=5)$. Agar treatments and controls include no nutrient addition (C), thioglycollate control (TC), nitrogen (N), phosphorus (P), and nitrogen + phosphorus $(\mathrm{N}+\mathrm{P})$. Bars represent mean values, and whisker bars represent $1 \mathrm{SE}$. Data were log transformed for statistical analysis. Letters refer to ANOVA where the same letters are not significantly different (ANOVA: $P<0.05$ ).

$\left(F_{1,16}=7.8, P=0.013\right)$. In Jackrabbit Spring, biofilm respiration suggested organisms were $\mathrm{N}$ and $\mathrm{P}$ colimited. Biofilm respiration yielded organismal activity that was $\mathrm{N}$ limited $\left(F_{1,16}\right.$ $=5.9, P=0.028)$, and $P$ limited $\left(F_{1,16}=7.0\right.$, $P=0.018)$, with the largest increase in respiration occurring in the $\mathrm{N}$ and $\mathrm{P}$ interaction $\left(F_{1,16}=6.3, P=0.023\right)$.

In contrast to respiration, biofilm biomass did not suggest organisms were nutrient limited in Devils Hole (Table 5). However, biofilm biomass in Jackrabbit Spring did suggest organisms were $\mathrm{N}$ and $\mathrm{P}$ colimited. The biofilm biomass indicated organisms were $\mathrm{N}$ limited $\left(F_{1,16}=53.8, P<0.001\right)$ and P limited $\left(F_{1,16}=116.5, P<0.001\right)$, and the interaction between $\mathrm{N}$ and $\mathrm{P}$ had the largest increase in biofilm growth $\left(F_{1,16}=19.6, P<\right.$ $0.001)$.

\section{Discussion}

In Devils Hole, we found that biofilm pore water had higher $\mathrm{NH}_{4}$ and $\mathrm{PO}_{4}$ concentrations than bulk water, suggesting biofilm release of nutrients. Also, the bulk water $\mathrm{SO}_{4}$ concentration and the pore water $\mathrm{NH}_{4}, \mathrm{SO}_{4}, \mathrm{PO}_{4}$, and $\mathrm{NO}_{3}$ concentrations were highest during indirect light as hypothesized, likely due to decreased assimilation. Additionally, we found that the biofilm temperature, $\mathrm{pH}$, and $\mathrm{O}_{2}$ concentration were highest during direct light, 
consistent with higher photosynthesis, as predicted. The $\mathrm{O}_{2}$ and $\mathrm{H}_{2} \mathrm{~S}$ concentrations also tended to have an inverse relationship, as hypothesized.

\section{Temporal Variation in Microbial Biofilm Characteristics}

Light exposure, biofilm type, and season influence microbial biofilm nutrient concentrations and physicochemical characteristics. Diurnal $\mathrm{O}_{2}$ concentrations were consistent with patterns found in temperate freshwater streams (Mulholland et al. 2005), and patterns in $\mathrm{H}_{2} \mathrm{~S}$ variation were consistent with measurements in saline desert lakes (Jørgensen 1977, Revsbech et al. 1983). Further, the ranges of diurnal $\mathrm{O}_{2}$ variation measured in this study were comparable to previous water column $\mathrm{O}_{2}$ measurements at Devils Hole (Bernot and Wilson 2012). However, maximum $\mathrm{O}_{2}$ concentrations during direct light were up to twice as high as previous Devils Hole measurements which did not take into account seasonal variation in biofilm $\mathrm{O}_{2}$ concentrations.

Temporal variation in physicochemical properties, especially $\mathrm{O}_{2}$, can create periods of stress on organisms in the environment if the conditions are inhospitable (Gustafson and Deacon 1998, Shepard et al. 2000). In the Devils Hole ecosystem, temperature and $\mathrm{pH}$ vary $<1$ order of magnitude spatially and temporally (Gustafson and Deacon 1998). However, bulk water $\mathrm{O}_{2}$ ranges from 2.4 to $4.1 \mathrm{mg}$. $\mathrm{L}^{-1}$; and in the biofilm, $\mathrm{O}_{2}$ ranges from 0 to $62.1 \mathrm{mg} \cdot \mathrm{L}^{-1}$. The high concentrations of $\mathrm{O}_{2}$ produced in the biofilm and diffused into the bulk water increase the ecosystem $\mathrm{O}_{2}$ concentration of the naturally low $\mathrm{O}_{2}$ groundwater. Thus, $\mathrm{O}_{2}$ concentration varies widely in the ecosystem, and the addition of $\mathrm{O}_{2}$ from biofilm production is likely critical to ecosystem structure and function. When exposed to stressful conditions such as low $\mathrm{O}_{2}$ and high temperatures, fish may change their behavior. For instance, rainbow trout (Oncorhynchus mykiss) can choose habitat locations based on trade-offs between temperature stress and dissolved oxygen stress (Matthews and Berg 1997). Further, when stressed by high temperatures and low $\mathrm{O}_{2}$, emerald shiners (Notropis atherinoides) may experience inhibited spawning (Matthews and Maness 1979). In Devils Hole, where temperatures average $33.5{ }^{\circ} \mathrm{C}$ year-round, $\mathrm{O}_{2}$ concentrations below
$2.0 \mathrm{mg} \cdot \mathrm{L}^{-1}$ can cause decreased larval success (Deacon et al. 1995). An Arizona relative of the endemic Devils Hole pupfish (Cyprinodon diabolis), the desert pupfish (Cyprinodon macularius), has an $\mathrm{LD}_{50}$ percent survivorship of $0.25 \mathrm{mg} \mathrm{O}_{2} \cdot \mathrm{L}^{-1}$ in experimental closed-air systems (Lowe et al. 1967). Additionally, low $\mathrm{O}_{2}$ and high temperatures can cause stress to invertebrates within the system which can alter community structure and organismal abundance (Davis 1975, Justus et al. 2014). Dissolved oxygen dynamics need to be understood to predict ecosystem and organismal response to changing environmental conditions.

\section{Spatial Variation in Microbial Biofilm Characteristics}

The $\mathrm{SO}_{4}, \mathrm{O}_{2}$, and $\mathrm{H}_{2} \mathrm{~S}$ concentrations in the microbial biofilms differed by biofilm type. Difference in biofilm types were characterized by increased $\mathrm{O}_{2}$ in photoautotrophic biofilms and increased $\mathrm{SO}_{4}$ and $\mathrm{H}_{2} \mathrm{~S}$ in sulfuroxidizing lithotrophic biofilms. The inverse relationship between $\mathrm{O}_{2}$ and $\mathrm{H}_{2} \mathrm{~S}$ was consistent with other studies in marine biofilm mats and experimental hypersaline ponds with sulfur-oxidizing bacteria (Fründ and Cohen 1992, de Beer et al. 1994). These variations yield distinct differences in the nutrient concentrations and physicochemical characteristics within different biofilm types. The autotrophic biofilms Spirogyra and cyanobacteria have high dissolved oxygen concentrations and low sulfide concentrations. In contrast, the heterotrophic biofilm Beggiatoa has low dissolved oxygen concentrations and high sulfide concentrations. These results are consistent with our hypothesis that there would be an inverse relationship between the dissolved oxygen and sulfide concentrations in Devils Hole biofilms. The distinct biofilms within Devils Hole are dispersed through the ecosystem (i.e., Spirogyra mats and Beggiatoa occur adjacent to one another and are mixed together and not isolated), and such arrangement may yield more consistent concentrations within the surrounding water column. It is not clear what physical aspects give rise to Beggiatoa biofilms given their dispersed nature in the ecosystem.

Hydrogen sulfide can be toxic to larvae and adult organisms in aquatic ecosystems (Erbe et al. 2011, Wang et al. 2011). For instance, 
Drotar et al. (1987) demonstrated that the $\mathrm{LC}_{50}$ of $\mathrm{H}_{2} \mathrm{~S}$ was $1.03 \mathrm{mg} \cdot \mathrm{L}^{-1}$ for the marine ciliate Tetrahymena thermophila. However, the $\mathrm{LC}_{50}$ experiment was conducted at $\mathrm{pH} 9$, whereas Devils Hole has a $\mathrm{pH}$ near 7.5. The maximum concentration of $\mathrm{H}_{2} \mathrm{~S}$ measured in Devils Hole was $27.7 \mathrm{mg} \cdot \mathrm{L}^{-1}$ at $>2$-cm depth into the biofilm, which is more than an order of magnitude higher than the $\mathrm{LC}_{50}$ measured by Drotar et al. (1987). The toxicity of $\mathrm{H}_{2} \mathrm{~S}$ makes it important for the livelihood of endemic organisms to prevent elevated $\mathrm{H}_{2} \mathrm{~S}$ concentrations from developing in Devils Hole and other aquatic ecosystems. Additionally, because $\mathrm{H}_{2} \mathrm{~S}$ is present in conjunction with Beggiatoa, an increase in Beggiatoa abundance could suggest increasing $\mathrm{H}_{2} \mathrm{~S}$ concentrations within the ecosystem, potentially yielding harmful effects on the organisms feeding on and living in the microbial biofilms.

The increased $\mathrm{SO}_{4}$ concentrations in Beggiatoa pore water, compared to bulk water and other biofilm types, provide evidence that $\mathrm{H}_{2} \mathrm{~S}$ oxidation was occurring by Beggiatoa. Furthermore, the increased pore water $\mathrm{SO}_{4}$ was present during direct light when photosynthetic biofilms increase the oxidation rate of $\mathrm{H}_{2} \mathrm{~S}$ (Hansen et al. 1978). The $\mathrm{H}_{2} \mathrm{~S}$ concentrations in Spirogyra and cyanobacteria were lower than in Beggiatoa and likely due to upward diffusion from underlying sediment or decomposing biofilm (Zinder et al. 1977). Complex relationships between biofilm type and $\mathrm{H}_{2} \mathrm{~S}$ dynamics exist within Devils Hole biofilms, demonstrating the importance of understanding microscale physicochemical differences in biofilms.

The variation in physicochemical properties of the 2 autotrophic microbial biofilms (Spirogyra and cyanobacteria) has implications for the ecosystem function of Devils Hole as well as other ecosystems with a heterogeneous microbial biofilm community. The physicochemical properties of the microbial biofilm and ecosystem may change if there is a shift in the abundance of different microbial biofilms. For instance, an algal bloom of Spirogyra in Devils Hole is attributed to decreased larval populations of Devils Hole pupfish in May 1997. This algal bloom caused greater midday biofilm temperatures and sections of the biofilm to float to the surface where the upper layer floating above the water surface desiccated (Gustafson and Deacon 1998). From
1999 to 2012 , time explained $17 \%$ of the variation in decreased cyanobacteria abundance (Fig. 2). A long-term decrease in cyanobacteria abundance could decrease the amount of dissolved $\mathrm{O}_{2}$ available in the ecosystem. Because Devils Hole is inherently a low- $\mathrm{O}_{2}$ habitat, decreased $\mathrm{O}_{2}$ concentration may negatively impact aquatic species dependent on the $\mathrm{O}_{2}$ produced by the microbial biofilms. Thus, decreased $\mathrm{O}_{2}$ concentration may cause endemic aquatic organisms to have lower population survivorship, juvenile recruitment, and metabolism, which may in turn decrease biodiversity or ecosystem stability (Deacon et al. 1995).

\section{Nutrient Limitation}

In this study, we compared nutrient limitation of autotrophic and heterotrophic microbes in 2 desert aquatic ecosystems. In Devils Hole, respiration was higher with $\mathrm{N}$ enrichment, suggesting that some organisms may be $\mathrm{N}$ limited. These results contradict a previous experiment where the algae Selenastrum was P limited in Devils Hole (Shepard et al. 2000). Any N limitation present in Devils Hole is probably driven by heterotrophic organisms. However, due to the steep rock walls surrounding Devils Hole, the photosynthetic biofilms are likely primarily light limited (Wilson and Blinn 2007). Light limitation has been shown to limit the growth of biofilms as well as reduce the frequency of detecting nutrient limitation in the biofilms (von Schiller et al. 2007, Elsaholi et al. 2011). Because of the low $\mathrm{N}$ concentration and the presence of cyanobacteria species that are capable of $\mathrm{N}$ fixation, it is possible that Devils Hole has biological N fixing occurring, though the abundance of $\mathrm{N}$-fixing organisms is unknown.

Unlike Devils Hole, Jackrabbit Spring organisms colonizing autotrophic and heterotrophic biofilms were $\mathrm{N}$ and $\mathrm{P}$ colimited in the presence of grazing and therefore did not have filamentous algae and bacterial colonization. Instead, the pores in the fritted glass discs and cellulose sponges had unicellular biofilm growth that was not grazed by endemic fishes. The difference between nutrient limitation and type of biofilm growth in Devils Hole and Jackrabbit Spring suggests that different types of algae and bacterial biofilms may be limited by different nutrients. However, this is not an example of community 
colimitation (Larned 2010) because the multiplenutrient limitation is increasing growth among only unicellular algae and bacteria and not the larger diversity of biofilm taxa represented in the Devils Hole samples (Francoeur 2001). The role of fish grazing on desert biofilms is important to consider, as invasive fish like largemouth bass (Micropterus salmoides) invade spring pools and prey upon endemic fishes (Miller 1948). In addition, desert spring alteration may threaten endemic fish survival (Riggs and Deacon 2002, Kodric-Brown and Brown 2007) which may result in decreased biofilm grazing. Also, introduction of invasive fishes to desert springs may increase the grazing pressure on biofilms (Kodric-Brown and Brown 2007). Anthropogenic changes to desert aquatic ecosystems, including habitat disturbance resulting in native fish extinction or the introduction of invasive fishes, may alter the biofilm community structure and therefore change the biofilm nutrient limitation.

Though the Jackrabbit Spring and Devils Hole sites are near each other geographically, their physiochemical characteristics differ. Nitrogen concentrations were lower in Jackrabbit Spring but oxygen concentrations were higher relative to Devils Hole. This is likely due to water movement within the ecosystems (more diffusion of oxygen into the water via turbulent flow in Jackrabbit Spring) as well as water source and surrounding inputs. Jackrabbit Spring hosts more grazing organisms which have a marked effect on microbial biofilms. Devils Hole has only one vertebrate, the endangered Devils Hole pupfish.

A novel $\mathrm{H}_{2} \mathrm{~S}$ NDS was developed because Devils Hole is known to have the sulfuroxidizing bacterium Beggiatoa. These unique enrichments had high rates of respiration overall, likely due to the selection for active anaerobic bacteria in addition to Beggiatoa. Beggiatoa growth is limited by the availability of sulfide or thiosulfate in the ecosystem (Nelson and Castenholz 1981). Furthermore, Beggiatoa growth is inhibited by high concentrations of dissolved oxygen (Schmidt et al. 1987). The concentration and spatial distribution of sulfide in the ecosystem could potentially promote or inhibit the growth of different microbes including Beggiatoa, cyanobacteria, and algae. Oscillatoria from Wilbur Hot Springs in California was able to carry out photoassimilation at $0.01 \mu \mathrm{g} \cdot \mathrm{L}^{-1} \mathrm{H}_{2} \mathrm{~S}$. In the presence of $\mathrm{H}_{2} \mathrm{~S}$, the photoassimilation rate of Oscillatoria increased to $120 \%$, suggesting $0.01 \mu \mathrm{g} \cdot \mathrm{L}^{-1} \mathrm{H}_{2} \mathrm{~S}$ promoted photosynthesis. However, Oscillatoria from Stinky Hot Springs, Utah, was sensitive to $\mathrm{H}_{2} \mathrm{~S}$ toxicity, and photosystem II was $50 \%$ inhibited at $0.0003 \mu \mathrm{g} \cdot \mathrm{L}^{-1}$ $\mathrm{H}_{2} \mathrm{~S}$. Spirogyra was unable to perform oxygenic photosynthesis in $\mathrm{H}_{2} \mathrm{~S}$ concentrations of $0.000008 \mu \mathrm{g} \cdot \mathrm{L}^{-1} \mathrm{H}_{2} \mathrm{~S}$ (Camacho et al. 2005).

Because Beggiatoa are found at the boundary between oxic and anoxic biofilms where there is $\mathrm{H}_{2} \mathrm{~S}$, a test of $\mathrm{H}_{2} \mathrm{~S}$ limitation is appropriate in the desert ecosystem.

\section{Comparison of Autotrophic and Heterotrophic Activity}

The Nutrient-Algal Biomass Conceptual Model (Munn et al. 2010) presents a framework by which to interpret biofilm biomass in relation to nutrient concentrations. The model postulates that at low nutrient concentrations when algal biomass is low, algae are limited by nutrients. Conversely, at high nutrient concentrations when algal biomass is high, there is nutrient saturation and growth plateaus. When nutrient concentrations are low and there is high algal biomass, algae reduce the measurable nutrients available in the water column via uptake. Additionally, when nutrient concentrations are high but algal biomass is low, other environmental factors (e.g., light) limit algal growth (Munn et al. 2010). Published results of chlorophyll $a$ being used as a predictor of algal biomass show that algal biomass generally explains $<50 \%$ of variation predicted by $\mathrm{N}$ and $\mathrm{P}$ nutrient concentration (Biggs 2000, Dodds et al. 2002). Other environmental factors including light (Hill and Knight 1988), substrata (Murdock and Dodds 2007), and scouring by flooding (Biggs 2000) commonly contribute to predicting biofilm biomass.

The Nutrient-Algal Biomass Conceptual Model provides a useful method to interpret the biofilm growth in Devils Hole and Jackrabbit Spring. Devils Hole has high algal biomass, as measured in AFDM; however, nutrient concentrations are low compared to agricultural or urban areas that are nutrient enriched. This low nutrient concentration could be attributed to high rates of nutrient assimilation by algae, according to the NutrientAlgal Biomass Conceptual Model. Unlike Devils Hole, Jackrabbit Spring has low algal 
biomass due to endemic fish grazing reducing filamentous algal growth. Algal growth is limited by the biological pressure of the grazing fish in the ecosystem.

The biofilm respiration in the desert ecosystems was comparable to sediment respiration measured in eastern U.S. streams (Hill et al. 2002). Devils Hole and Jackrabbit Spring biofilm respiration was within one order of magnitude of mean sediment respiration measured in Hill et al. (2002). The TC treatment with anoxic agar in Devils Hole and Jackrabbit Spring had the highest respiration, suggesting that there were more abundant respiring bacteria in anoxic conditions compared to oxic conditions. Heterotrophic nutrient limitation in the biofilm of springs is important because of the role biofilms play in production, respiration, and decomposition. Tank and Dodds (2003) studied algal and fungal limitation in 10 streams and found the biomass response to nutrient limitation differed between autotrophs and heterotrophs. In contrast, we found general consistency in nutrient limitation of autotrophic and heterotrophic growth. Rier and Stevenson (2002) found a positive relationship between autotrophic and heterotrophic growth because the bacteria colonize algae as a substrata. The algal nutrient limitation limited algal substrata for bacterial colonization, which thereby influenced the respiration rate.

\section{Conclusions}

The impact of changing physicochemical characteristics within microbial biofilms and bulk water may impact other trophic levels in the ecosystem. For example, temperature stress decreases the specific growth rate of desert pupfishes endemic to freshwater ecosystems throughout the desert Southwest. At $36{ }^{\circ} \mathrm{C}$, desert pupfish (Cyprinodon nevadensis) are unable to assimilate enough food to maintain positive growth rates and $60 \%$ mortality can result (Gerking and Lee 1983). Furthermore, a shift in biofilm abundance in Devils Hole may change the type of food available for endemic fish and the physicochemical properties of the benthos where invertebrates and fish eggs exist (Deacon et al. 1995). In the past 12 years, Devils Hole has increased in seasonal Spirogyra abundance and decreased in cyanobacteria biofilm abundance (Fig. 2), which suggests a community shift. The cause of this community shift is unknown, but differences measured among biofilms suggest there could be physicochemical changes to the Devils Hole ecosystem outside the range of conditions required for growth of endemic species. Further, increasing Spirogyra abundance has been linked to eutrophication (Nweze and Onyishi 2011). The increasing Spirogyra may indicate that this system is receiving increased nutrients from outside sources, though nutrients remain low due to high nutrient demand causing the assimilation of all available nutrients (Munn et al. 2010). In the context of a rapidly changing environment, understanding the possible nutrient enrichment of the Devils Hole ecosystem can provide insight on other desert aquatic ecosystems.

\section{ACKNOWLEDGMENTS}

We thank Ball State Graduate Student Research Program, Death Valley Conservation Fund, Offield Family Foundation, and National Science Foundation IDBR (EAGER)1011787 for funding; Lindy Caffo and Ann Raffel for laboratory assistance; Bailey Gaines and Courtney Crismore for field assistance; and Jason Doll for statistical assistance. Additionally, we thank Randy Bernot and James Mitchell for support and discussion of the research and 3 anonymous reviewers for helpful suggestions that improved the manuscript.

\section{Literature Cited}

Barranguet, C., B. Veuger, S.M. Van Beusekom, P. Marvan, J.J. Sinke, and W. Admiraal. 2005. Divergent composition of algal-bacterial biofilms developing under various external factors. European Journal of Phycology 40:1-8.

Bernot, M.J., AND K.P. WiLSON. 2012. Spatial and temporal variation of dissolved oxygen and ecosystem energetics in Devils Hole, Nevada. Western North American Naturalist 72:265-275.

BIgGS, B.J.F. 2000. Eutrophication of streams and rivers: dissolved nutrient-chlorophyll relationships for benthic algae. Journal of the North American Benthological Society 19:17-31.

Biggs, B.J.F., AND C. Kilroy. 2000. Stream periphyton monitoring manual. New Zealand Ministry for the Environment and Nation Institute of Water and Atmospheric Research.

Biggs, B.J.F., AND R.L. Lowe. 1994. Responses of two trophic levels to patch enrichment along a New Zealand stream continuum. New Zealand Journal of Marine and Freshwater Resources 28:119-134.

Bryan, J.R., J.P. Rlley, and P.J.L. Williams. 1976. A winkler procedure for making precise measurements 
of oxygen concentration for productivity and related studies. Journal of Experimental Marine Biology and Ecology 21:191-197.

Bunch, A., AND M. Bernot. 2011. Distribution of nonprescription pharmaceuticals in central Indiana streams and effects on sediment microbial activity. Ecotoxicology 20:97-109.

Camacho, A., C. Rochera, J.J. Silvestre, E. Vicente, AND M.W. HAHN. 2005. Spatial dominance and inorganic carbon assimilation by conspicuous autotrophic biofilms in a physical and chemical gradient of a cold sulfurous spring: the role of differential ecological strategies. Microbial Ecology 50:172-184.

CLINE, J.D. 1969. Spectrophotometric determination of hydrogen sulfide in natural waters. Limnology and Oceanography 14:454-458.

DAVIS, J.C. 1975. Minimal dissolved oxygen requirements of aquatic life with emphasis on Canadian species: a review. Journal of the Fisheries Research Board of Canada 32:2295-2332.

de Beer, D., P. Stoodley, F. Roe, and Z. Lewandowski. 1994. Effects of biofilm structures on oxygen distribution and mass transport. Biotechnology and Bioengineering 43:1131-1138.

Deacon, J.E., F.R. Taylor, and J.W. Pedretti. 1995. Egg viability and ecology of Devils Hole pupfish: insights from captive propagation. Southwestern Naturalist 40:216-223.

Diffenbaugh, N.S., F. Giorgi, and J.S. Pal. 2008. Climate change hotspots in the United States. Geophysical Research Letters 35:L16709.

DodDs, W.K., V.H. Smith, AND K. Lohman. 2002. Nitrogen and phosphorus relationships to benthic algal biomass in temperate streams. Canandian Jounal of Fisheries and Aquatic Science 59:865-874

Drotar, A., L.R. Fall, E.A. Mishalanie, J.E. Tavernier, AND R. FALL. 1987. Enzymatic methylation of sulfide, selenide, and organic thiols by Tetrahymena thermophila. Applied and Environmental Microbiology 53:2111-2118.

Eaton, A.D., L.S. Clesceri, W.E. Rice, and A.E. GREENBERG. 2005. Standard methods for examination of water and wastewater. 21st edition. American Public Health Association.

Elsaholi, M.S., E. Hannigan, and M. Kelly-Quinn. 2011. Nutrient and light limitation of algal biomass in selected streams in Ireland. Inland Waters $1: 74-80$.

Erbe, M.C.L., W.A. Ramsdorf, T. Vicari, and M.M. CESTARI. 2011. Toxicity evaluation of water samples collected near a hospital waste landfill through bioassays of genotoxicity piscine micronucleus test and comet assay in fish Astyanax and ecotoxicity Vibrio fischeri and Daphnia magna. Ecotoxicology 20:320-328.

Fairchild, G.W., R.L. Lowe, and W.B. Richardson. 1985. Algal periphyton growth on nutrient-diffusing substrates: an in situ bioassay. Ecology 66:465-472.

Francoeur, S.N. 2001. Meta-analysis of lotic nutrient amendment experiments: detecting and quantifying subtle responses. Journal of the North American Benthological Society 20:358-368.

Fründ, C., AND Y. COHEN. 1992. Diurnal cycles of sulfate reduction under oxic conditions in cyanobacterial mats. Applied and Environmental Microbiology 58: $70-77$.
Gerking, S.D., And R.M. LeE. 1983. Thermal limits for growth and reproduction in the desert pupfish Cyprinodon n. nevadensis. Physiological Zoology 56: $1-9$.

Grimm, N.B., R.W. Sheibley, C.L. Crenshaw, C.N. Dahm, W.J. RoACH, AND L.H. ZEgLin. 2005. N retention and transformation in urban streams. Journal of the North American Benthological Society 24: 626-642.

Gustafson, E.S., and J.E. Deacon. 1998. Distribution of larval Devils Hole pupfish, Cyprinodon diabolis Wales, in relation to dissolved oxygen concentration in Devils Hole. Final report, Death Valley National Park, 1.

Hansen, M.H., K. Ingvorsen, and B.B. Jørgensen. 1978. Mechanisms of hydrogen sulfide release from coastal marine sediments to the atmosphere. Limnology and Oceanography 23:68-76.

Hill, B.H., A.T. Herlihy, and P.R. Kaufmann. 2002. Benthic microbial respiration in Appalachian Mountain, Piedmont, and Coastal Plains streams of the eastern U.S.A. Freshwater Biology 47:185-194.

Hill, W.R., AND A.W. KNight. 1988. Nutrient and light limitations of algae in two northern California streams. Journal of Phycology 24:125-132.

Hoellein, T.J., J.L. Tank, J.J. Kelly, and E.J. RosiMarShaLl. 2010. Seasonal variation in nutrient limitation of microbial biofilms colonizing organic and inorganic substrata in streams. Hydrobiologia 649: 331-345.

James, C.J. 1969. Aspects of the ecology of the Devils Hole Pupfish (Cyprinodon diabolis). Master's thesis, University of Nevada, Las Vegas, NV.

Jeroschewski, P., C. SteucKart, and M. KÜHL. 1996. An amperometric microsensor for the determination of $\mathrm{H}_{2} \mathrm{~S}$ in aquatic environments. Analytical Chemistry 68:4351-4357.

Johnson, L.T, J.L. Tank, and W.K. Dodds. 2009. The influence of land use on stream biofilm nutrient limitation across eight North American ecoregions. Canadian Journal of Fisheries and Aquatic Sciences 66:1081-1094.

Jørgensen, B.B. 1977. The sulfur cycle of a coastal marine sediment (Limfjorden, Denmark). Limnology and Oceanography 22:814-832.

Justus, B., S. Mize, J. Wallace, and D. Kroes. 2014. Invertebrate and fish assemblage relations to dissolved oxygen minima in lowland streams of southwestern Louisiana. River Research Applications 30:11-28.

Kodric-Brown, A., AND J.H. Brown. 2007. Native fishes, exotic mammals, and the conservation of desert springs. Frontiers in Ecology and the Environment 5:549-553.

LARNED, S.T. 2010. A prospectus for periphyton: recent and future ecological research. Journal of the North American Benthological Society 29:182-206.

Lowe, C.H., D.H. Hinds, and E.A. Halpern. 1967. Experimental catastrophic selection and tolerances to low oxygen concentration in native Arizona freshwater fishes. Ecology 48:1013-1017.

Matthews, K., and N. Berg. 1997. Rainbow trout responses to water temperature and dissolved oxygen stress in two southern California stream pools. Journal of Fish Biology 50:50-67.

Matthews, W.J., And J.D. Maness. 1979. Critical thermal maxima, oxygen tolerances and success of cyprinid 
fishes in a southwestern river. American Midland Naturalist 102:374-377.

MilleR, R.R. 1948. The cyprinodon fishes of the Death Valley system of eastern California and southwestern Nevada. Miscellaneous Publications of the Museum of Zoology, University of Michigan 68:1-155.

Mulholland, P.J., J.N. Houser, and K.O. Maloney. 2005. Stream diurnal dissolved oxygen profiles as indicators of in-stream metabolism and disturbance effects: Fort Benning as a case study. Ecological Indicators 5:243-252.

Munn, M., J. Frey, and A. Tesoriero. 2010. The influence of nutrients and physical habitat in regulating algal biomass in agricultural streams. Environmental Management 45:603-615.

Murdock, J.N., AND W.K. DodDs. 2007. Linking benthic algal biomass to stream substratum topography. Journal of Phycology 43:449-460.

Murdock, J.N., AND D.L. WeTZEL. 2009. FT-IR microspectroscopy enhances biological and ecological analysis of algae. Applied Spectroscopy Review 44: 335-361.

Nelson, D.C., and R.W. Castenholz. 1981. Use of reduced sulfur compounds by Beggiatoa sp. Journal of Bacteriology 147:140-154.

NweZe, N.O., AND U.E. ONYISHI. 2011. Phycological effects of eutrophication with fertilizers in Nike Lake, Nigeria. Journal of Water Resource and Protection 3:856-860.

Pringle, C.M., P. Paaby-Hansen, P.D. Vaux, and C.R. Goldman. 1986. In situ nutrient assays of periphyton growth in a lowland Costa Rican stream. Hydrobiologia 134:207-213.

R Development Core Team. 2011. R: a language and environment for statistical computing. R Foundation for Statistical Computing, Vienna, Austria: R Foundational for Statistical Computing. http://www .R-project.org

Revsbech, N.P., and B. Jørgensen. 1986. Microelectrodes: their use in microbial ecology. Advances in Microbial Ecology 9:293-352.

Revsbech, N.P., B. Jørgensen, T.H. Blackburn, and Y. CoHEn. 1983. Microelectrode studies of the photosynthesis and $\mathrm{O}_{2}, \mathrm{H}, \mathrm{S}$, and $\mathrm{pH}$ profiles of a microbial mat. Limnology and Oceanography 28:1062-1074.

Rier, S.T., and R.J. STEvenson. 2002. Effects of light, dissolved organic carbon, and inorganic nutrients on the relationship between algae and heterotrophic bacteria in stream periphyton. Hydrobiologia 489: 179-184.

Riggs, A.C., and J.E. Deacon. 2002. Connectivity in desert aquatic ecosystems: the Devils Hole story. Conference proceedings. Spring-fed wetlands: important scientific and cultural resources of the Intermountain Region. Vol. 11.

Rugenski, A.T., A.M. Marcarelli, H.A. Bechtold, and R.S. INOUYE. 2008. Effects of temperature and concentration on nutrient release rates from nutrient diffusing substrates. Journal of the North American Benthological Society 27:52-57.
SADA, D.W., AND G.L. Vinyard. 2002. Anthropogenic changes in biogeography of Great Basin aquatic biota. Smithsonian Contributions to the Earth Sciences 33:277-293.

Schmidt, T., B. Arieli, Y. Cohen, E. Padan, and W. STROHL. 1987. Sulfur metabolism in Beggiatoa alba. Journal of Bacteriology 169:5466-5472.

Seager, R., M. Ting, I. Held, Y. Kushnir, J. Lu, G. Vecchi, H.-P. Huang, N. Harnik, A. LeetmaA, N.-C. Lau, C. LI, J. VELEZ, AND N. NAIK. 2007. Model projections of an imminent transition to a more arid climate in southwestern North America. Science 316:1181-1184.

Shepard, W.D., D.W. Blinn, R.J. Hoffman, and P.T. Kantz. 2000. Algae of Devils Hole, Nevada, Death Valley National Park. Western North American Naturalist 60:410-419.

Tank, J.L., M.J. Bernot, and E.J. Rosi-Marshall. 2006. Nitrogen limitation and uptake. Pages 213-238 in F.R Hauer and G.A. Lamberti, editors, Methods in Stream Ecology. Elsevier, New York, NY.

TANK, J.L., AND W.K. DodDs. 2003. Nutrient limitation of epilithic and epixylic biofilms in ten North American streams. Freshwater Biology 48:1031-1049.

TANK, J.L., AND J. WEBSTER. 1998. Interaction of substrate and nutrient availability on wood biofilm processes in streams. Ecology 79:2168-2179.

Trevors, J.T. 1984. The measurement of electron transport system (ETS) activity in freshwater sediment. Water Research 18:581-584.

von Schiller, D., E. Martí, J.L. Riera, and F. Sabater. 2007. Effects of nutrients and light on periphyton biomass and nitrogen uptake in Mediterranean streams with contrasting land uses. Freshwater Biology 52: 891-906.

Wang, C., R. Yu, and M. Zhou. 2011. Acute toxicity of live and decomposing green alga Ulva (Enteromorpha) prolifera to abalone Haliotis discus hannai. Chinese Journal of Oceanology and Limnology 29:541-546.

WiLson, K.P., AND D.W. BLINN. 2007. Food web structure, energetics, and importance of allochthonous carbon in a desert cavernous limnocrene: Devils Hole, Nevada. Western North American Naturalist 67: $185-198$.

Winkler, L.W. 1888. Die Bestimmung des im Wasser gelösten Sauerstoffes. Berichte der deutschen chemischen Gesellschaft 21:2843-2854.

Winograd, I.J., and F.J. Pearson. 1976. Major carbon 14 anomaly in a regional carbonate aquifer: possible evidence for megascale channeling, South Central Great Basin. Water Resourses Research 12:1125-1143.

Zinder, S., W. Doemel, and T. Brock. 1977. Production of volatile sulfur compounds during the decomposition of algal mats. Applied and Enviromental Microbiology 34:859-860.

Received 6 April 2015 Accepted 30 September 2015 